\title{
Sosyal Medya Konulu Araştırmaların Bilim Haritalama Tekniği ile Bibliyometrik Analizi
}

DOI: $10.26466 /$ opus.680835

$*$

\author{
Serdar Akyıldız - Kadri Gökhan Yılmaz ** \\ * Dr. Öğr., Gazi Üniversitesi, Yönetim Bilişim Sistemleri Ana Bilim Dalı, Çankaya/Ankara/Türkiye \\ E-Posta: serdaragonder@gmail.com ORCID: 0000-0002-1536-5390 \\ ** Doç. Dr., Ankara Hacı Bayram Veli Üniversitesi İ.̇̇.B.F, Beşevler/Ankara/Türkiye \\ E-Posta: g.yilmaz@hbv.edu.tr ORCID: 0000-0002-3702-1070
}

\begin{abstract}
Öz
Sosyal medya, kullanıcıların oluşturdukları içerikleri paylaşmak üzere, elektronik iletişim araçları yoluyla meydana gelen çevrimiçi topluluklar olarak tanımlanabilir. Özellikle son yıllarda sosyal medyanın hızla artan kullanım oranı, sosyal medyayı yalnızca kişilerarası iletişim ortamı olmaktan çıkarmıs, toplumsal bir iletişim aracı haline dönüştürmüş̧ür. Günümüzde sosyal medya eğitim ve öğretim faaliyetlerinde, siyasal iletişim kampanyalarında, işletmelerde, kurumsal imaj çalışmalarında, kamu diplomasisinde, uluslararası ilişkilerde, hayata dair birçok alanda ve bilimsel çalışmalarda etkin bir şekilde kullanılmaktadır. Sosyal medya hayatın odak noktasında tüm paydaşlar tarafindan içselleştirilen bir olgu haline geldiğinden, sosyal medya alanında yapılan araştırmaların tematik gelişim haritasının ortaya konulması, yeni trendlerin takip edilebilmesi açısından önem kazanmaktadır. Bu amaçla hazırlanan bu araştırma ile sosyal medya alanında son on beş yılda yaşanan gelişmeler dönemsel olarak incelenmiştir. Araştırmada ilk olarak Web of Science (WoS) Core Collection veri tabanından araştırmada kullanılacak olan makale verileri elde edilmiştir. 04.12.2019 tarihinde WoS veri tabanında "Social Media" terimi "başlık" sekmesinde taranmış ve 17.406 yayına ulaşılmıştır. Sadece "makale" tipindeki yayınlar seçilerek 9.516 makale verisi için Science Mapping Analysis Tool (SciMAT) programı ile bilim haritalaması yöntemiyle bibliyometrik analiz yapılmıştır. Sosyal medya alanındaki gelişimi dönemler bazında değerlendirebilmek için makale verileri "2005-2009", "2010-2014" ve "2015-2019" şeklinde beşer yillık üç periyot halinde karşılaştırmalı olarak analiz edilmiştir. Yapılan analizler sonucunda, son dönemde sosyal medya alanında yayınlanan makale sayısının belirgin şekilde artış gösterdiği, ABD'nin en fazla yayın yapılan ülke olduğu, "2005-2009" döneminin motor temasının "sosyal medya", "2010-2014" döneminin ana motor temalarmın "sosyal medya", "katılım", "ağgzdan ağıza pazarlama", "ağ", "2015-2019" döneminin ana motor temalarının "sosyal medya", "ağızdan ağıza pazarlama", "politik katılım" ve "ergenler" olduğu görülmüştür.
\end{abstract}

Anahtar Kelimeler: Sosyal Medya, Bilim Haritalama, Bibliyometrik Analiz, SciMAT 


\title{
Bibliometric Analysis of Research on Social Media With Science Mapping Technique
}

\begin{abstract}
Social media can be defined as online communities formed through electronic means of communication in order to share users' content they create. Especially in recent years, rapidly increasing use rate of social media has transformed social media from being only an interpersonal medium and turned into a social communication tool. Social media is now used effectively in education and training activities, political communication campaigns, businesses, corporate image studies, public diplomacy, international relation, in many areas related to life and scientific studies. Since social media has become a phenomenon internalized by all stakeholders at the focal point of life, revealing the thematic development map of the research in the field of social media is important in terms of following new trends. With this research prepared for this purpose, the developments in the field of social media in the last fifteen years were examined periodically. First of all, article data to be used in the research were obtained from the Web of Science (WoS) Core Collection database. On 04.12.2019, the term "social media" was searched in the "title" tab in the WoS database and 17.406 publications were reached. Only "article" type publications were selected and a bibliometric analysis was conducted for 9.516 article data using the Science Mapping Analysis Tool (SciMAT) program and science mapping method. In order to evaluate the developments in the field of social media on a periodic basis, the data of the articles were analyzed comparatively in three five-year periods as "2005-2009", "2010-2014" and "2015-2019". As a result of the analyzes, it is seen that the number of articles published in the field of social media has increased significantly, the USA is the most published country, "social media" was the engine theme of the "20052009" period, "social media", "participation", "word of mouth marketing", "network" were the engine theme of the "2010-2014" period, "social media", "word of mouth marketing", "political participation" and "adolescents" were the engine theme of "2015-2019" period.
\end{abstract}

Keywords: Social Media, Science Mapping, Bibliometric Analysis, SciMAT 


\section{Giriş}

Teknolojinin çok hızlı bir şekilde ilerlemesi, internetin hem kullanım hızının hem de kullanım alanının genişlemesi ile birlikte gerek sosyal alanlarda gerekse iş hayatında eski alışkanlıkların ve iş görme şekillerinin birçoğu değişikliğe uğramış, bu değişiklikler hayatımıza sosyal medya gibi birçok yeni kavramın girmesini sağlamıştır (Kaplan ve Haenlein, 2010).

Medya kelimesi, Latince'de ortada olan şey, aracı anlamına gelen "medium" kelimesinin çoğulu olup "iletişim ortamı, iletişim araçları" anlamına gelmektedir (Budak, 2015, s.11). Bunlar televizyon, radyo, dergi, gazete, kitap ve internet gibi basın ve yayın araçları ile birlikte Facebook, Twitter, Instagram ve Youtube gibi sosyal medya araçlarıdır.

Parr (2008) sosyal medyayı enformasyon ve deneyimleri internet ve elektronik cihazlar aracılığıyla diğer kullanıcılarla paylaşmak ve tartışmak için oluşturulan etkili yollar olarak tanımlamaktadır. Dolayısıyla sosyal medya, kullanıcıların internet dâhilinde birçok platform aracılı̆̆ ile gereksinimlerini karşılamak amaciyla kurdukları etkileşimlerdir.

\section{Sosyal Medyanın Ortaya Çıkışı ve Gelişimi}

Sosyal medya, 1995 yllından itibaren "world wide web (www)" teknolojisinin yayılmasıyla ortaya çıkan bir kavramdır. Bilindiği üzere web teknolojisi, Web 1.0 ile başlayan ve günümüzde Web 4.0'a ulaşan bir evrim geçirmiştir (Aghaei, Nematbakhsh ve Farsani, 2012). Web 1.0 (read-only web), kullanıcılara sınırlı etkileşim imkânı sağlayan, yalnızca bilginin araştırılıp okunmasına izin veren bir teknolojidir. Web 2.0 (read-write web), sosyal etkileşim vasitasiyla büyük global toplulukların bir araya getirilmesine ve yönetilmesine imkân sağlayan bir teknolojidir. Web 3.0 (semantic web), web üzerinde makine ile okunabilen içerikler sağlayarak, insanların görevlerini ve kararlarını makinelere bırakmayı arzulayan bir teknolojidir. Web 4.0 (read-write-execution-concurrency web) ise insan beyni ile makinenin ortak bir alanda (simbiyoz) etkileşime geçebildiği bir teknolojidir (Aghaei vd., 2012). 
Sosyal medya, yukarıda ifade edilen ve sosyal etkileşime olanak sağlayan Web 2.0 teknolojisinin gelişmesiyle ortaya çımış ${ }^{1}$ ve bugün sosyal, siyasi, ekonomik ve kültürel iletişimin vazgeçilmez bir parçası haline gelmiştir (Acet, 2013, s.37).

\section{Sosyal Medya Araçları}

Sosyal medya araçları, oluşturulma amacı ve içerik kıstas alınarak bloglar, mikrobloglar, wikiler, sosyal ağlar, video paylaşım ağları, fotoğraf paylaşım ağları, ses ve müzik paylaşım ağları, lokasyon araçları, sosyal işaretleme ağları ve sanal dünyalar olarak sinıflandırılabilir (Bostanc, 2015, s.58).

\section{Bloglar ve Mikro Bloglar}

Blog, web günlüğü anlamına gelen "webblog" kelimesinin kısaltılmış halidir. Bloglar vasıtasıyla kişiler, ilgi alanları hakkındaki düşünce ve görüşlerini, tutumlarını, denetimden geçirmeksizin diğer kullanıcılarla paylaşma imkânı bulurlar. Aynı zamanda bloglar, kullanıcılar için arşiv işlevi de görmektedir. Bloglarda içerikler, yazı formatının yanında ses ve görüntü formatında da aktarılabilmektedir (Çakmak, 2014, s.76-77).

Sosyal medyanın ilk örneklerinden biri olan bloglar, genellikle belli bir tarihsel sıralama içinde girilen içeriklerin bulunduğu, kişisel web sitelerinin sosyal medyadaki karşılıkları olarak tanımlanmaktadır (Kaplan ve Haenlein, 2010).

Mikrobloglar ise bloglardan kısa, anlık mesajlaşmalardan ise uzun olan paylaşımları ifade eder. Dünyada en yaygın mikroblog "Twitter" dır. Bu sayede paylaşılan içerik çok kısa sürede milyonlarca kişiye ulaşabilmekte ve aynı anda iletişim süreci başlayabilmektedir (Karaca, 2019, s.44).

Twitter mobil cihazlardan veya bilgisayarlardan kullanılabilen, geniş bir kullanıc ağına sahip bir uygulamadır. Bu nedenle enformasyon çok geniş kitleler arasında çok kısa bir sürede yayılabilmektedir. Bu kullanım yaygınlığı ve geniş ağ haberlerin doğrudan kaynağından ve olayın gerçekleştiği coğrafi

\footnotetext{
${ }^{1}$ Bilinen ilk sosyal medya ağı 1997-2001 yılları arasında faaliyet gösteren "SixDegrees.com"dur. Bu ağ sayesinde kullanıcılar, arkadaş listesi oluşturabilmekte, listede gezinebilmekte ve görüntü oluşturabilmekteydiler (Kaynak https://www.cbsnews.com/pictures/then-and-now-a-history-of-social-networking-sites/2/
} 
konumdan yayılmasına olanak sağlar (Castillo, Mendoza ve Poblete, 2011, s.675-684).

\section{Wiki}

Kullanıcı tarafından oluşturulan içeriği çevrimiçi oluşturma, birleştirme, iş birliği yapma, düzenleme ve paylaşmanın yeni yolları olan Web 2.0 teknolojilerinin sürekli gelişimi ile (Churchill, 2009), Wiki hem çevrimiçi hem de karma öğrenme ortamlarındaki en önemli araçlardan biri olarak ortaya çıkmıştır (Wheeler S., Yeomans ve Wheeler D., 2008).

Wiki, sayfa yaratabilecek ve sayfaların içeriğini düzenleyebilecek, sayfalar arasında bağlantılar oluşturabilecek, grafik ekleyebilecek ve videoları sayfalara ekleyebilecek üye kullanıcılar tarafından düzenlenebilen bir sayfa koleksiyonundan oluşmaktadır (Su ve Beaumont, 2010). Dünyada en çok bilinen wiki sitesi, ansiklopedi hizmeti sunan "wikipedia.org"dur.

\section{Sosyal Ağlar}

En popüler ve yüksek profilli sosyal medya araçlarından olan sosyal ağ siteleri, insanların kendi web sayfalarını oluşturmalarına, bu sayfalar üzerinden içerikleri paylaşmalarına ve çevrimiçi olarak arkadaşlarıyla iletişim kurmalarına olanak tanır (Mayfield, 2008). Aktif sosyal medya kullanıc hesaplarına veya her bir platformun tekil ziyaretçi istatistiklerine göre dünyada en popüler sosyal medya platformu "Facebook"dur (Wearesocial, 2019). Bunun yanında MySpace, Friendster gibi kişisel arkadaşlık temelli sosyal ağlar ile birlikte, Linkedin gibi mesleki amaçlı olan sosyal ağ siteleri de bulunmaktadır.

\section{İcerik Paylaşım Toplulukları}

İçerik paylaşım toplulukları, medya içeriklerinin kullanıcılar arasında paylaşılabilmesi amacıyla oluşturulmuş ortamlar olarak tanımlanabilir. Bu içerikler video, fotoğraf, metin ya da başka formatlarda olabilmektedir (Kaplan ve Haenlein, 2010). Bu sosyal paylaşım platformları, kullanıcıların etkileşim sağlamasıyla birlikte eğlenmeve çeşitli konularda bilgi edinme gibi birçok amaçla kullanılabilmektedir. Etkin kullanıcı hesaplarına veya her bir platformun tekil ziyaretçi istatistiklerine göre, dünyada bu amaçla kullanılan en 
yaygın içerik paylaşım platformları, Youtube ve Instagram'dır (Wearesocial, 2019).

Son zamanlarda sosyal medyanın en dikkat çekenlerinden biri de, özellikle yaşadığın ânı, fotoğraf veya videolar ile filtreler uygulayarakgönderme ve paylaşmaya adanmış bir sosyal medya platformu olan Instagram olmasıdır. Instagram kullanıcıları, başkalarının hesapların "takip edebilir", hashtag (\#) kullanarak belirli içerikleri arayabilir, paylaşılan gönderileri kendi hesaplarında yeniden paylaşabilir, paylaşımlara "beğen" veya "yorum" yapabilirler (Tiggemann ve Anderberg, 2019). Instagram, aynı zamanda 1 milyardan fazla aktif kullanıcısı olan dünya çapında en popüler sosyal paylaşım platformlarından biri haline gelmiştir (Statista, 2019a). Amerika Birleşik Devletleri'nde, 18-29 yaşları arasındaki genç yetişkinler arasında çok popülerdir (Statista, 2019b).

\section{Sosyal İşaretleme (İmleme) Ağlarn}

Sosyal işaretleme (imleme) ağları vasıtasıyla kullanıcılar, beğendikleri video, fotoğraf, kitap veya herhangi bir ürünü etiketleyerek diğer kullanıcılarla paylaşmaktadırlar. En yaygın kullanılan sosyal işaretleme ağ 1 "Pinterest" dir.

\section{Sosyal Medyanın Özellikleri}

Mayfield (2008)' a göre sosyal medya platformlarının kendilerine has bazı özellikler vardır. Sosyal medyanın önemli olan beş temel özelliğinden bahsetmektedir. Bunlar; katılımcılık, açıklık, diyalog, topluluk ve bağlanabilirlik özellikleridir(Mayfield, 2008). Bu özellikler aşağıda kısaca açılanmıştır:

Katılımcılık: Sosyal medya, kullanıcıları fikir ve görüşlerini açıklamaya cesaretlendiren bir niteliğe sahiptir. Bu sayede kullanıcılar arasındaki sınır ortadan kalkar.

Açıklık: Sosyal medya katılıma ve karşılıklı etkileşime daima açıktır. Bu sayede eleştiride bulunma, görüş bildirme, oylama vb. faaliyetler her zaman yapılabilir. 
Diyalog: Sosyal medyanın geleneksel medyadan ayırt edici en önemli özelliği belki de karşılıklı diyaloga imkân vermesidir. Bu durum, kullanıcıları pasif bilgi alıcısı olmaktan kurtararak onları aktif bir konuma getirir. Bunun yanında diyalog asimetrik değil simetriktir, bu sayede kullanıcılar görüşlerini özgürce ifade etme olanağı bulurlar.

Topluluk: Sosyal medya ilgi alanları ayn ya da benzer olan insanların topluluk oluşturmasına imkân sağlar. Böylece kullanıcılar ilgi alanlarına yönelik karşılıklı paylaşımda bulunabilir, sohbet edebilir ve görüş alışverişinde bulunabilirler.

Bağlanabilirlik: Sosyal medya kullanıcıları, erişim sağladığı sosyal medya platformu içerisinde bağlantı oluşturabildiği gibi, diğer sosyal medya platformları ile veya çevrimiçi web adresleri ile de bağlantı sağlayarak kullanıc1lar arası etkileşimi oluşturabilmektedir.

\section{Sosyal Medyanın Önemi}

Teknolojik gelişmeler iletişim kanallarına da etkilemiş ve insanlara paylaşım ve tartışma imkânı tanıyan yeni medya ortamını oluşturmuştur. Sosyal medya olarak adlandırılan bu sanal ortam, kullanıc tabanlı olmasının yanında, kitleleri ve insanları bir araya getirmesi ve aralarındaki etkileşimi arttırması bakımından önem taşımaktadır (Vural ve Bat).

Bazı endüstri guruları, Facebook, YouTube veya buna benzer sosyal medya araçların kullanmayan kuruluşların artık siber uzayın bir parçası olamayacağını iddia etmektedir. Sosyal medya, işletmelerin nispeten düşük maliyetle ve geleneksel iletişim araçlarıyla elde edilenden daha yüksek verimlilik düzeylerinde, zamanında ve doğrudan son tüketici ile iletişime girmelerini sağlayabilmektedir. Bu durum, sosyal medyayı yalnızca büyük ölçekli işletmeler için değil, aynı zamanda küçük ve orta ölçekli işletmeler, hatta kar amacı gütmeyen kuruluşlar ve devlet kurumları için de önemli kılmaktadır (Kaplan ve Haenlein, 2010).

Sosyal medyanın kullanım alanı gün geçtikçe artmaktadır. We Are Social (2019) Ekim 2019 Global raporuna göre, dünya nüfusunun yaklaşık \%48'i (3,725 milyar) aktif olarak sosyal medyayı kullanırken, bir yıl içerisinde (Ekim 
2018-Ekim 2019) kullanıcı sayısında \%9,6 oranında artış gerçekleştiği görülmüştür. Bahse konu bu raporda dünyada en çok kullanılan sosyal medya araçlarının başında 2,414 milyar kullanıcı ile Facebook ve 2 milyar kullanıcı ile Youtube olduğu görülürken, 1 milyar Instagram kullanıcısı bulunmaktadır. Aktif sosyal medya kullanıcı sayısı en çok artan platform ise Instagram olmuştur. Dolayısıyla sosyal medya kullanımı, çok sayıda insan hayatında geniş bir yer tutarken, birçok konuda da kullanıcıların ihtiyaç duydukları mecralar haline gelmiştir.

\section{Sosyal Medya Alanında Yapılan Yayınlar}

Google arama motorunda "sosyal medya" anahtar kelimesi kullanılarak yapılan taramada yaklaşık 208.000.000, "social media" anahtar kelimesi kullanılarak yapılan aramada ise yaklaşık 9.420 .000 .000 sonuç bulunmuştur. ${ }^{2}$ Web of Science (2019) veri tabanında 1975-2019 yılları arasında "Social Media" terimi "başlık" sekmesinde tarandığında ise 17.406 yayına ulaşılmaktadır.

Yükseköğretim kurulunun (2019) tez veri tabanında "sosyal medya" anahtar kelimesi kullanılarak yapılan arama sonucunda 786 tane yayın olduğu görülmüştür. Bunlardan 101 tanesi doktora, 7 tanesi tıpta uzmanlık, geriye kalan 681 tanesi ise yüksek lisans tezidir. Konu bakımından yapılan taramada ise bu tezlerin; 4 tanesi aile hekimliği, 2 tanesi bankacılık, 3 tanesi beslenme ve diyetetik, 5 tanesi bilgi ve belge yönetimi, 24 tanesi bilgisayar mühendisliği, 21 tanesi bilim ve teknoloji, 8 tanesi din, 4 tanesi endüstri ve endüstri mühendisliği, 63 tanesi eğitim ve öğretim, 3 tanesi felsefe, 51 tanesi gazetecilik, 4 tanesi güzel sanatlar, 88 tanesi halkla ilişkiler, 7 tanesi hastane yönetimi ve hemşirelik, 2 tanesi hukuk, 73 tanesi iletişim bilimleri, 167 tanesi işletme, 11 tanesi kamu yönetimi, 78 tanesi psikiyatri ve psikoloji, 16 tanesi radyo ve televizyon, 32 tanesi reklamcllk, 20 tanesi siyasal bilimler, 29 tanesi sosyoloji ve 21 tanesinin ise turizm alanında yazıldığ

Son olarak DergiPark (2019) arama motorunda, "sosyal medya" anahtar kelimesi kullanılarak yapılan tarama sonucunda 1036 tane makalenin bulunduğu görülmüştür.

\footnotetext{
${ }^{2}$ Erişim tarihi: 10/01/2020.
} 


\section{Araştırmanın Yöntemi}

\section{Amaçve Önem}

$\mathrm{Bu}$ araştırmanın amacı, sosyal medya kavramsal yapısında son on beş yılda yaşanan gelişmeleri dönemsel ve sistematik olarak incelemektir. Bu çerçevede, yapılan ilgili alan yazın incelemesinde "sosyal medya konulu araştırmaların bilim haritalama tekniği ile bibliyometrik analizi" konusunda yap1lan ilk çalışmalardan olma önemine sahiptir.

\section{Veri Toplama Yöntemi ve Bibliyometrik Analizler}

Pritchard (1969) tarafindan 1960'ların sonlarında "matematiğin ve istatistiksel yöntemlerin kitaplara ve diğer iletişim araçlarına uygulanması" olarak ortaya çıkan "bibliyometri" terimi, disiplin sınırı koymaksızın kaydedilen kitap, makale, yayın, alıntı vb. bilgilerin istatistiksel olarak anlamlı bir şekilde tezahür etmesidir (Bellis, 2009). Broadus (1987) bibliyometriyi tanımlarken, "fiziksel yayınlanmış yayınların veya bibliyografik yayınların niceliksel çalışması" olarak ifade etsede 2000'li yıllarda elektronik yayınların artması bu tanıma elektronik yayınları da dahil etmiştir.

Bibliometrik ölçümler, inceleme sırasında toplanan kaynakça materyallerini göstermek için oldukça kullanışlıdır (Cancino, Merigó, Coronado, Dessouky ve Dessouky, 2017). Petticrew ve Roberts (2008), bibliyometrik ölçümler gibi sistematik gözden geçirmelerin, daha alakalı ve güncel sonuçların elde edilmesini sağlayan farklı veri tabanlarından örnekler toplayarak daha verimli sonuçlar elde edeceğini savunmuşlardır. Bu bağlamda bibliyometrik analizler, nicel bir araştırma tekniği olup keşfedici ve tanımlayıcı çalışmalar olarak değerlendirilmektedir. Bu analizler geleneksel yöntemlerle yapılabildiği gibi, analize uygun verilerle çalışılabilen bazı yazılımlar vasıtasıyla da yapılabilmektedir (Kurutkan ve Orhan, 2018a).

Günümüzde, bilim haritalama veya bibliyometrik araştırmalar yapmada kullanılabilecek çok sayıda veri tabanlarından en fazla tercih edilenleri WoS, Scopus, Google Scholar, PubMed, MEDLINE veri tabanlarıdır (Chen, 2017). WoS ve Scopus arasındaki karşılaştırmalarda her iki vertitabanının atıf sayılarında birbirine yakın sonuçların ortaya çıktığı; yayın sayılarına her iki veri- 
tabanının konu kategorilerine göre bakıldığında, Scopus'ın WoS'a göre yaşam ve sağlık bilimlerinde, WoS'un ise yayın içeriği yönünden sosyal bilimlere daha fazla ağırlık verdiği tespit edilmiştir (Jacso, 2005). WoS, sosyal bilimler alanında çok sayıda nitelikli dergiyi kapsamına almaktadır. Araştırmacılara analiz yapmada büyük kolaylıklar sağlamakta, veri tabanları içerisinde ise dünyadaki en prestijli veri tabanlarından biri olması sebebiyle de bu araştırmada tercih edilmiştir (Demir ve Erigüç, 2018).

\section{Arama Stratejisi ve SciMAT Program}

Bibliyometrik analizlerde bir takım frekans analizleri (yayın sayısı, toplam atıf sayısı, h-indeks vb.) de verilmekle birlikte, bu analizler kendi içerisinde sistematik olarak çalışan yapı ve algoritmalar ile verileri işleyen araçlardır. $\mathrm{Bu}$ programlardan bir tanesi olan SciMAT programında araştırmaya dâhil edilen veriler, belirlenen dönemler bazında karşılaştırmalı olarak analiz edilebilmektedir. Kullanılan analiz birimleri -bu araştırmada kelimeler- arasındaki ilişkiler belli algoritmalarla program tarafından işlenmekte, her döneme ilişkin ilgilenilen alan için önemli olan kavramsal yapılar belirlenmekte, dönemler arasındaki ilişkilerin değerlendirilmesini de sağlayacak şekilde bulgular görselleştirilmekte, ortaya çıkan önemli yapılar ile ilgili kalite değerlendirme ölçütleri de verilmekte ve böylece bulguların bir bütün olarak araştırmacı tarafından değerlendirilmesine imkân sağlanmaktadır (Cobo, López-Herrera, Herrera-Viedma ve Herrera, 2012).

Bu bağlamda, sosyal medya konusu ile ilgili tematik gelişimi bilim haritalama yöntemiyle yapmamıza olanak sağlayan SciMAT programında analiz edilecek gerekli makale verileri WoS Core Collection veri tabanından elde edilmiştir. 04.12.2019 tarihinde WoS veri tabanında 1975-2019 yılları arası "Social Media" terimi “başlık" sekmesinde taranmış ve ilk yayın 2005 yılına ait olmak üzere 17.406 yayına ulaşılmıştır. Sadece "makale" tipindeki yayınlar seçilerek 9.696 makaleye ulaşılmış ve bu makale verileri "plain text" formatında indirilerek bilim haritalaması yapılması için SciMAT programına yüklenmiştir. Bilim haritalama yapılabilen en önemli programlardan olan SciMAT (2019) programı, ücretsiz bir yazılım olmakla birlikte; kod, formül ve rehberleri kendi sitelerinde bulunmaktadır. Bu program, karar almayı kolaylaştıran zengin görsel özelliklere sahip olduğundan (Kurutkan ve Orhan, 2018b) bu araştırmada kullanılmıştır. 
SciMAT programına verilerin yüklenmesi sonrasında yapılan incelemede 180 makale verisinin yıl bilgisinin eksik olduğu belirlenmiş ve bu makaleler analizden çıkartılarak 9.516 makale verisi ile analizlere devam edilmiştir. Bu aşamada araştırmada kullanılan makalelere ilişkin anahtar kelimelerde tekilçoğul durumları, kısaltma yapılanlar, yazın yanlışları bulunanlar ve eş anlamlılıkları dikkate alınarak düzeltmeler sağlanmıştır.

Wos veri tabanı içerisinde, sosyal medya başlıklı makaleler tarandığında 2005-2019 yılları arasında 15 yıllık dönemde yayın yapıldığı görülmüştür. Sosyal medya alanındaki gelişimi dönemler bazında değerlendirebilmek için ise makale verileri "2005-2009", “2010-2014" ve “2015-2019” şeklinde beşer yıllık üç eşit periyot şeklinde gruplandırılmıştır. Periyotlarda yer alan makale sayıları Diyagram 1'de belirtilmiştir. Son beş yıl içerisinde yapılan çalışma sayılarının belirgin bir şekilde artış gösterdiği görülmektedir.

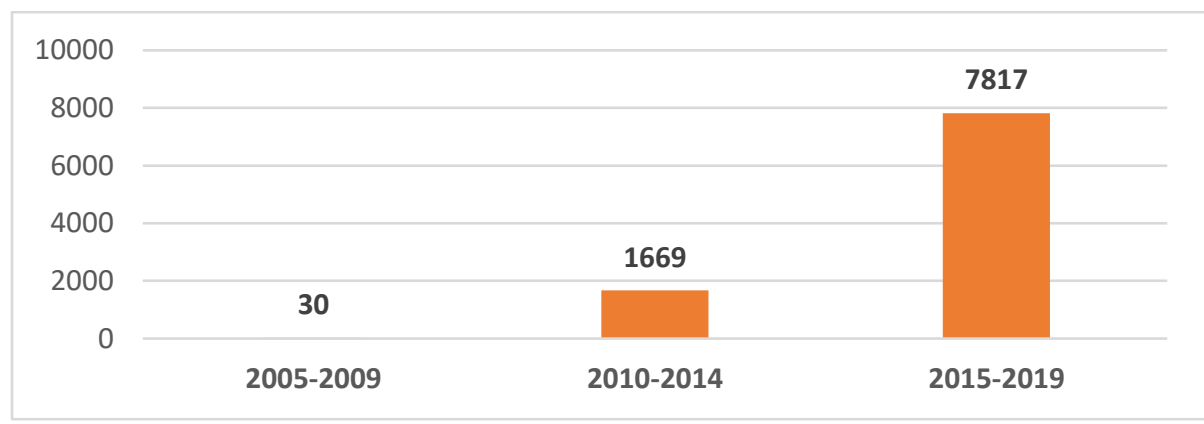

Diyagram 1. Yayınlanan Makale Sayılar

Analizlerde kullanılacak olan verilerin düzenlenmesinden sonra yorumlanabilir düzeyde bulguların elde edilebilmesi için analiz programında veri indirgemesi yapılmış (Cobo vd., 2012) ve analiz birimi olarak kelimeler seçilmiştir (Cobo, Martínez, Gutiérrez-Salcedo, Fujita, ve Herrera-Viedma, 2015). Bu kelimelerin seçilmesinde;

Matris türü seçiminde anahtar kelimelerin birlikte kullanılma sıklıklarının dikkate alındığg "co-occurrence",

Normalizasyon işleminde anahtar kelimelerin kullanım sıklıkları ve birlikte bulunma oranlarının değerlendirilebilmesi için "equivalence index",

Tema kümelerinin oluşturulmasında algoritma seçeneği olarak "simple centers algorithm", 
Bulguların stratejik diyagram, tematik ağ, örtüşüm haritası ve tematik gelişim haritası ile değerlendirilmesi için "core mapper",

Temaların kalite değerlendirmeleri için "h-index (Martínez, Cobo, Herrera, ve Herrera-Viedma, 2015) ve toplam atıf sayısı",

Tematik gelişim haritasında ve örtüşüm haritasında dönemler arasında boylamsal analize imkân sağlayabilmek için ise "inclussion index" seçenekleri kullanılmıştır (Murgado-Armenteros, Gutiérrez-Salcedo, Torres-Ruiz ve Cobo, 2015).

Araştırma bulgularının değerlendirilmesinde stratejik diyagramlar, tematik ağlar ve tematik gelişim haritası kullanılmıştır. Stratejik diyagramda temalar merkezilik ve yoğunluk düzeylerine göre yerleşmekte, diyagramdaki dairelerin büyüklüğü ilgili tema ile ilişkili bilimsel yayın sayısı ile orantılı olarak değişmekte ve daireler içerisindeki rakamlar bilimsel yayın sayısını göstermektedir. Merkezilik, temaların diğer temalarla olan ilişkisini ifade etmekte ve diyagramda sağa yaklaştıkça merkezilik düzeyi artmaktadır. Yoğunluk, temaların gelişmişliğini göstermekte ve diyagramda yukarı çıkıdıkça yoğunluk artış göstermektedir. Temalar merkezilik ve yoğunluklarına göre dört farklı alanda yer almaktadır (Cobo vd., 2012). Sağ üst alanda merkezilik ve yoğunlukları yüksek olan "motor temalar", sağ alt alanda merkeziliği yüksek fakat yoğunluğu düşük "temel ve dönüşümsel temalar", sol üst alanda merkeziliği düşük fakat yoğunluğu yüksek "gelişmiş ve izole temalar", sol alt alanda merkeziliği ve yoğunluğu düşük "ortaya çıan veya kaybolan temalar" bulunmaktadır (Cobo vd., 2015). Tematik ağlarda temaların kendi aralarındaki ilişkiler görülmekte ve çizgilerin kalınlığı ilişkinin derecesine göre değişmektedir (Martínez vd., 2015). Tematik ağların değerlendirilmesinde, temalar arasındaki ilişkilerin gücü ağırlık (weight) değerleri ile verilmiştir. Tematik gelişim haritasında temaların dönemler arasındaki ilişkileri değerlendirilmektedir. Düz çizgiler temalar arasında aynı anahtar kelimelerin paylaşıldığını, kesikli çizgiler ise tema adları dışındaki ortak kelimelerin paylaşıldığını göstermektedir. Çizgilerin kalınlığı ise ilişkilerin derecesine göre artmakta (Murgado-Armenteros vd., 2015) ve ilişkinin kuvvet derecesini göstermektedir. Yani, çizgi kalınlaştığında ilişkinin kuvveti artarken, çizgi inceldikçe ilişkinin kuvvet derecesi azalmaktadır (Tabak, Barbak ve Öztürk, 2016). 


\section{Bulgular}

WoS veri tabanından indirilen makalelerin yayınlandığ 1 ülkelere göre dağılımı Diyagram 2'de yer almaktadır.

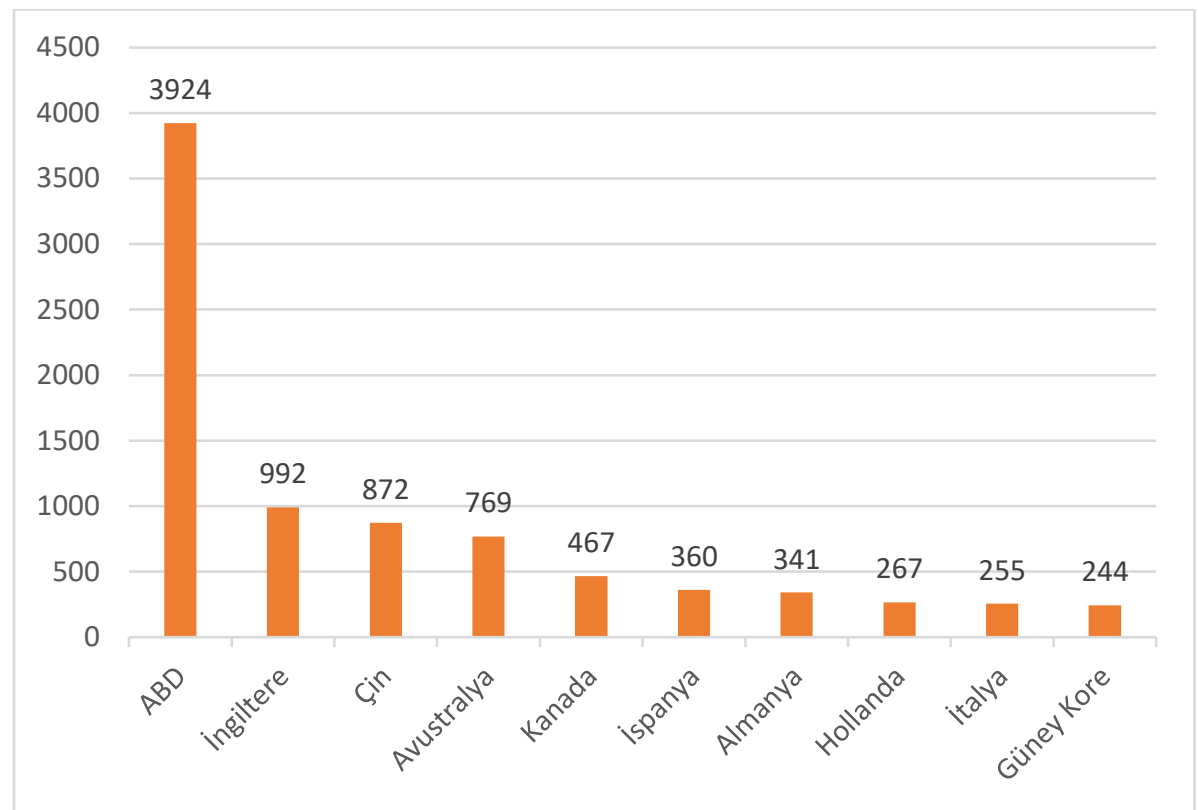

Diyagram 2. Makalelerin Ülkelere Göre Dağılımı

ABD'nin belirgin bir şekilde diğer ülkelerden daha fazla sosyal medya alanında yayın yaptığı $(\% 40)$, bu ülkeyi İngiltere (\%10) ve Çin'in (\%8,9) takip ettiği görülmektedir. Türkiye ise ülkeler sıralamasında 202 araştırmayla 11. sırada yer alarak, tüm araştırmaların \%2'lik kısmını oluşturmuştur. Ayrıca, yayınların yaklaşık \%97'si İngilizce olarak yayımlanırken, 39 araştırma ise Türkçe yayımlanmıştır. Sosyal medya alanında Türkçe yayınların tüm araştırmalar içerisinde ki oranı yaklaşık olarak $\% 0,4^{\prime}$ tür.

\section{5-2009 Dönemi Sosyal Medya Konusunun Gelişimi}

Analizler sonucunda ortaya çkan 2005-2009 dönemine ait stratejik diyagram Diyagram 3'te yer almaktadır. 


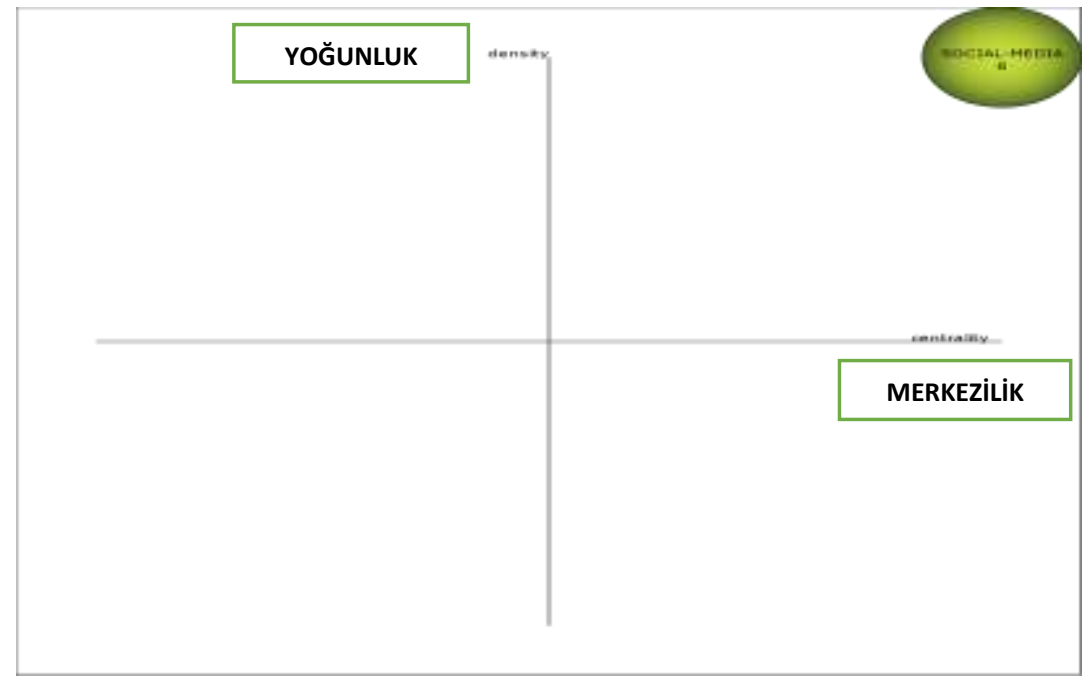

Diyagram 3. 2005-2009 Dönemi Stratejik Diyagramı

Sosyal medya konusunun henüz yeni olduğu ve farklı alanlarla birlikte sosyal medya ile yapılan çalışma sayısı oldukça az olduğundan, bu dönemde yalnızca "social media" teması ortaya çıkmıştır.

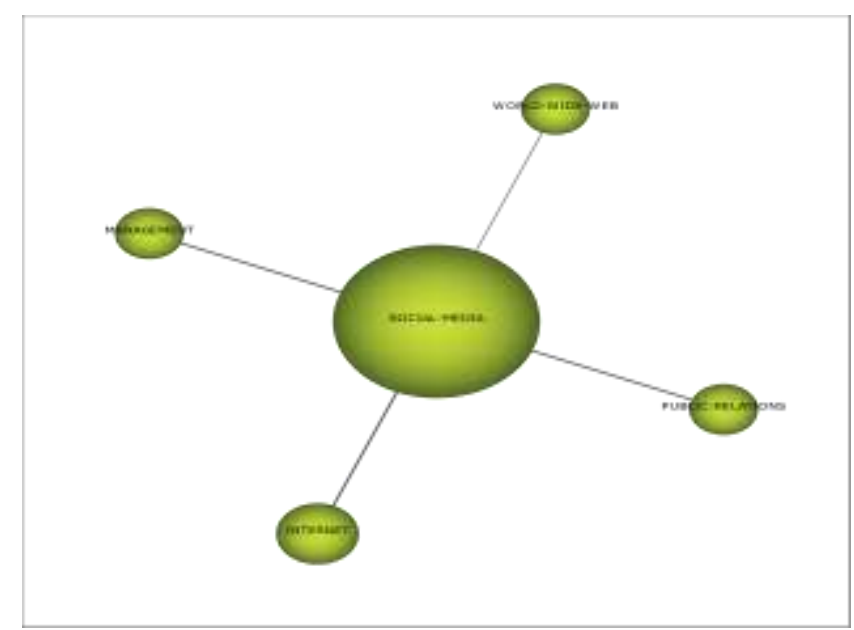

Diyagram 4. Sosyal Medya Tematik Ă̆ı

Diyagram 4'te verilen tematik ağda görüldügü üzere "social media" teması "management" $(\mathrm{w}=0,17)$, "internet" $(\mathrm{w}=0,25)$, "public relations" 
$(\mathrm{w}=0,17)$ ve "world wide web" $(\mathrm{w}=0,04)$ temaları ile ilişkilidir. Bu dönemin motor teması olan "social media" temasıyla ilişkili olarak 6 makale yayınlanmıştır ve bu temanın toplam atıf sayısının 718, h-indeksinin ise 6 olduğu belirlenmiştir.

\section{0-2014 Dönemi Sosyal Medya Konusunun Gelişimi}

2010-2014 dönemine ait analizler sonucunda ortaya çıkan veriler Diyagram 5 'te yer almaktadir.

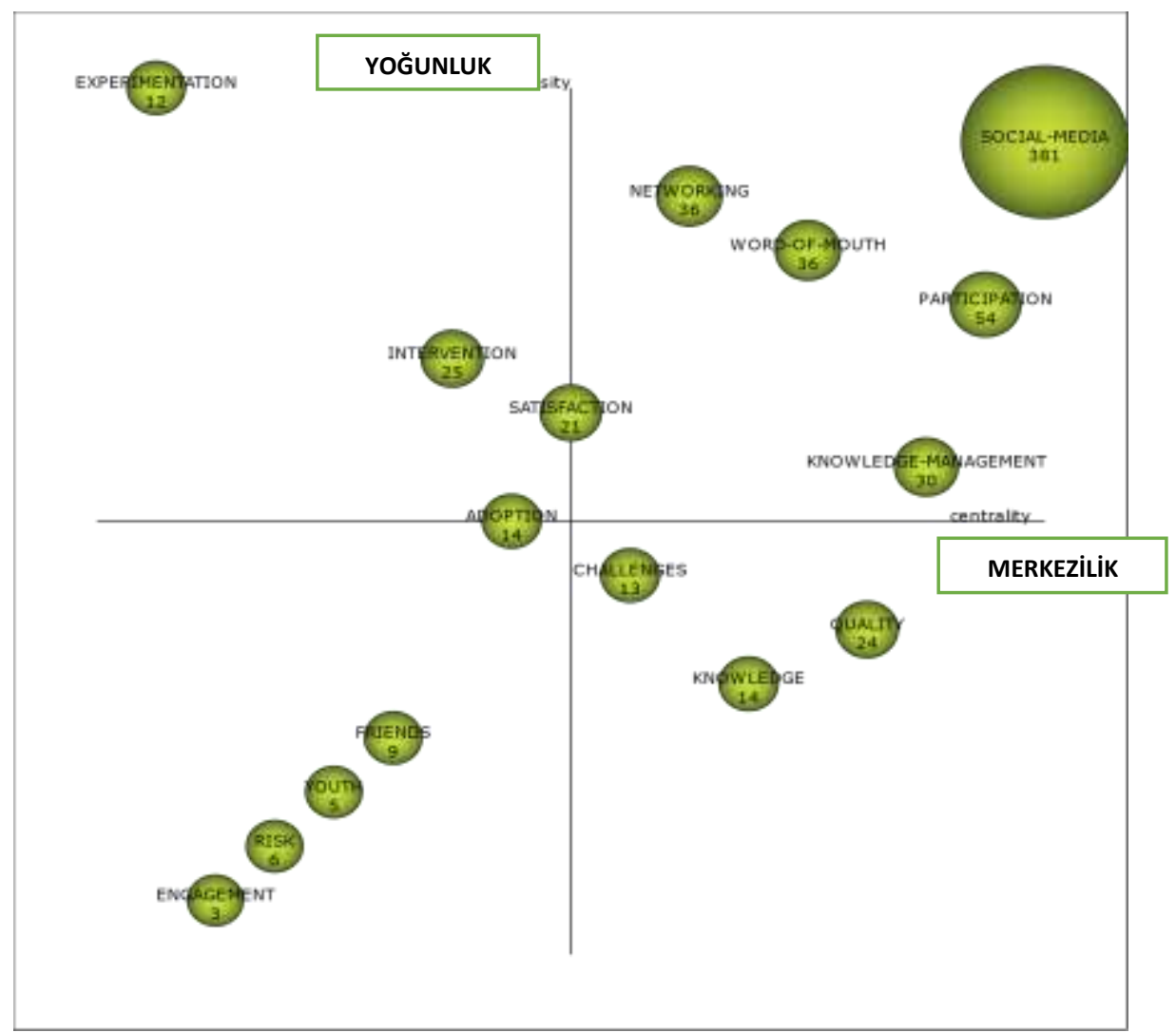

Diyagram 5. 2010-2014 Dönemi Stratejik Diyagramı

Stratejik diyagramda görüldüğü üzere bu dönemde toplam 16 tema ortaya çıkmıştır. Bu dönemin motor temalar "social media", "participation", 
"word of mouth", "networking", "knowledge management"; temel ve dönüşümsel temalarn "quality", "knowledge", "challenges"; gelişmiş ve izole temalar "experimentation", "intervention", "satısfaction", "adoption"; ortaya çıkan veya kaybolan temalar "friends", "youth", "risk", "engagement" temalarıdır.

Bu dönemde özellikle, "social media", "participation", "word of mouth", "networking", "knowledge management" sosyal medya çalışmalarının motor temasını oluşturmaktadır. "Social media" dan sonra, "participation" ilgili yapılan sosyal medya çalışmaları nispeten hem sayısal olarak yoğundur hem de diğer tematik alanlarla en fazla ilişki içerisindedir. Özellikle "experimentation", sonrasinda "intervention", "satisfaction", "adoption" sosyal medya alanında yoğun olarak çalışılmakla birlikte diğer tematik alanlar ile bağlarının zayıf olduğu görülmektedir. Gelişmiş ve izole temalar; "quality", "knowledge", "challenges" ise sosyal medya alanının gelişimi için önemli olan ancak yeterince çalışılmamış temalardır. Ortaya çıkan veya kaybolan temalar; "friends", "youth", "risk", "engagement" hem az çalışılmış hem de diğer tematik alanlar ile ilişki kuvveti zayıf olan temalardır.

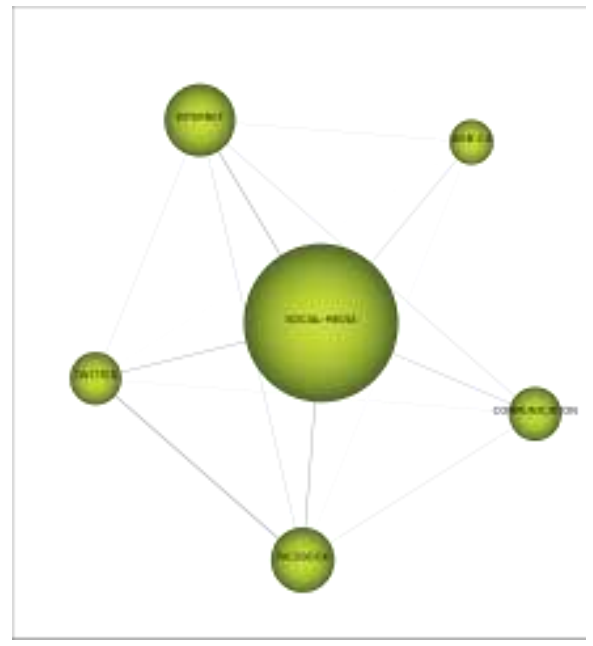

A: Social Media

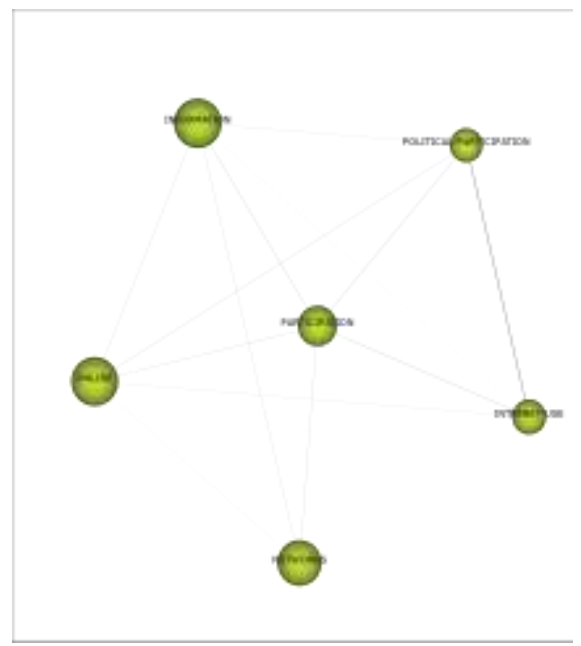

B: Participation 


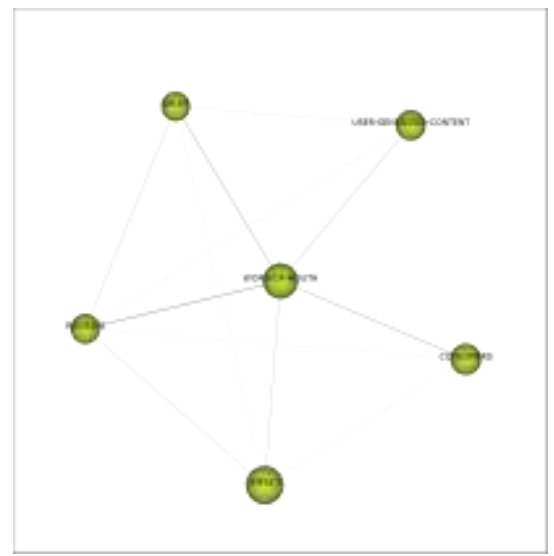

C: Word of mouth

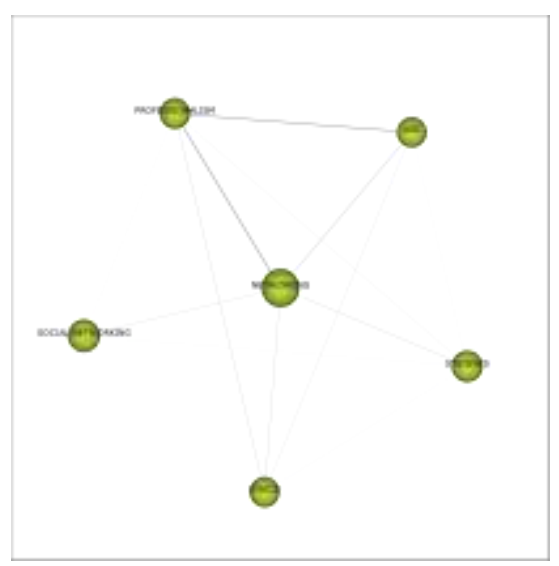

D: Networking

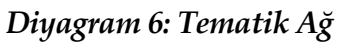

Tablo 1. 2010-2014 Dönemi Temalarına İlişkin Bulgular

\begin{tabular}{llll}
\hline İsim & Doküman Sayıs & Atıf Sayıs & h-İndeksi \\
\hline Social media & 381 & 27,390 & 75 \\
\hline Participation & 54 & 4,131 & 27 \\
\hline Word of mouth & 36 & 3,622 & 26 \\
\hline Networking & 36 & 1,163 & 17 \\
\hline Knowledge management & 30 & 1,375 & 16 \\
\hline Intervention & 25 & 1,145 & 16 \\
\hline Quality & 24 & 1,704 & 16 \\
\hline Satisfaction & 21 & 2,507 & 16 \\
\hline Adoption & 14 & 510 & 9 \\
\hline Knowledge & 14 & 795 & 9 \\
\hline Challenges & 13 & 288 & 8 \\
\hline Experimentation & 12 & 396 & 9 \\
\hline Friends & 9 & 394 & 6 \\
\hline Risk & 6 & 86 & 4 \\
\hline Youth & 5 & 41 & 3 \\
\hline Engagement & 3 & 76 & \\
\hline
\end{tabular}

“Diyagram 6: Tematik Ağ" ve “Tablo 1: 2010-2014 Dönemi Temalarına İlişkin Bulgular"da, 2010-2014 Dönemi öne çıan motor temaların hangi konularla beraber çalışıldığı ve bu motor temaların bilimsel verileri aşağıda sunulmuştur.

Diyagram 6A'da verilen tematik ağda belirtildiği gibi "social media" teması "internet" $(w=0,12)$, "twitter" $(w=0,09)$, "facebook" ( $w=0,10)$, "communication" $(\mathrm{w}=0,07)$ ve "Web 2.0" $(\mathrm{w}=0,05)$ temaları ile ilişkilidir. Bu dönemin 
motor temalarından olan "social media" temasıyla ilişkili olarak 381 makale yayınlanmış ve bu temanın toplam atıf sayısının 27.390, h-indeksinin ise 75 olduğu belirlenmiştir.

Diyagram $6 \mathrm{~B}^{\prime}$ de verilen tematik ağda belirtildiği gibi "participation" teması "information" $(\mathrm{w}=0,03)$, "online" $(\mathrm{w}=0,03)$, "networks" $(\mathrm{w}=0,03)$, "internet use" $(w=0,04)$ ve "political participation" $(w=0,03)$ temaları ile ilişkilidir. Motor temalardan olan "participation" temasiyla ilişkili olarak 54 makale yayınlanmış ve bu temanın toplam atıf sayısının 4.131, h-indeksinin ise 27 olduğu belirlenmiştir.

Diyagram $6 C^{\prime}$ de verilen tematik ağda belirtildiği gibi "word of mouth" temas1 "sales" $(w=0,09)$, "reviews" $(w=0,13)$, "impact" $(w=0,04)$, "consumers" $(\mathrm{w}=0,08)$ ve "user generated content" $(\mathrm{w}=0,04)$ temaları ile ilişkilidir. Motor temalardan olan "word of mouth" temasıyla ilişkili olarak 36 makale yayınlanmış ve bu temanın toplam atıf sayısının 3.622, h-indeksinin ise 26 olduğu belirlenmiştir.

Diyagram 6D'de verilen tematik ağda belirtildiği gibi "networking" temasi "professionalizm" $(\mathrm{w}=0,15)$, "social networking" $(\mathrm{w}=0,02)$, "ethics" $(w=0,03)$, "students" $(w=0,03)$ ve "age" $(w=0,05)$ temaları ile ilişkilidir. Motor temalardan olan "networking" temasıyla ilişkili olarak 36 makale yayınlanmış ve bu temanın toplam atıf sayısının 1.163, h-indeksinin ise 17 olduğu belirlenmiştir.

\section{5-2019 Dönemi Sosyal Medya Konusunun Gelişimi}

Analizler sonucunda ortaya çıan 2015-2019 dönemine ait stratejik diyagram Diyagram 7'de yer almaktadır.

Stratejik diyagramda görüldüğü üzere bu dönemde toplam 23 tema ortaya çıkmıştır. Bu dönemin motor temaları "social media", "adolescents", "word of mouth", "political participation", "intention", "adoption", "college students", "loyalty", "management", "perceptions", "participation"; temel ve dönüşümsel temaları "intervention"; gelişmiş ve izole temaları "politics"; ortaya çıkan veya kaybolan temalar ise "self", "systems", "education", "privacy", "sentiment", "instagram", “campaigns", “women", "time", "network sites" temaları olmuştur. 
Bu dönemde özellikle, sosyal medya alanında yapılan çalışmalarda motor temanın 10 farklı konuda oluşması ve bu temalardan 8 tanesinin ilk defa motor tema olarak yer alması oldukça dikkat çekicidir. Bu durum, birçok bilim dalında sosyal medya konusuna yer verildiği ve sosyal medyanın artan önemine işaret etmektedir. "Participation" ve "word of mouth" ise bir önceki dönemde olduğu gibi motor tema olmaya devam etmiştir.

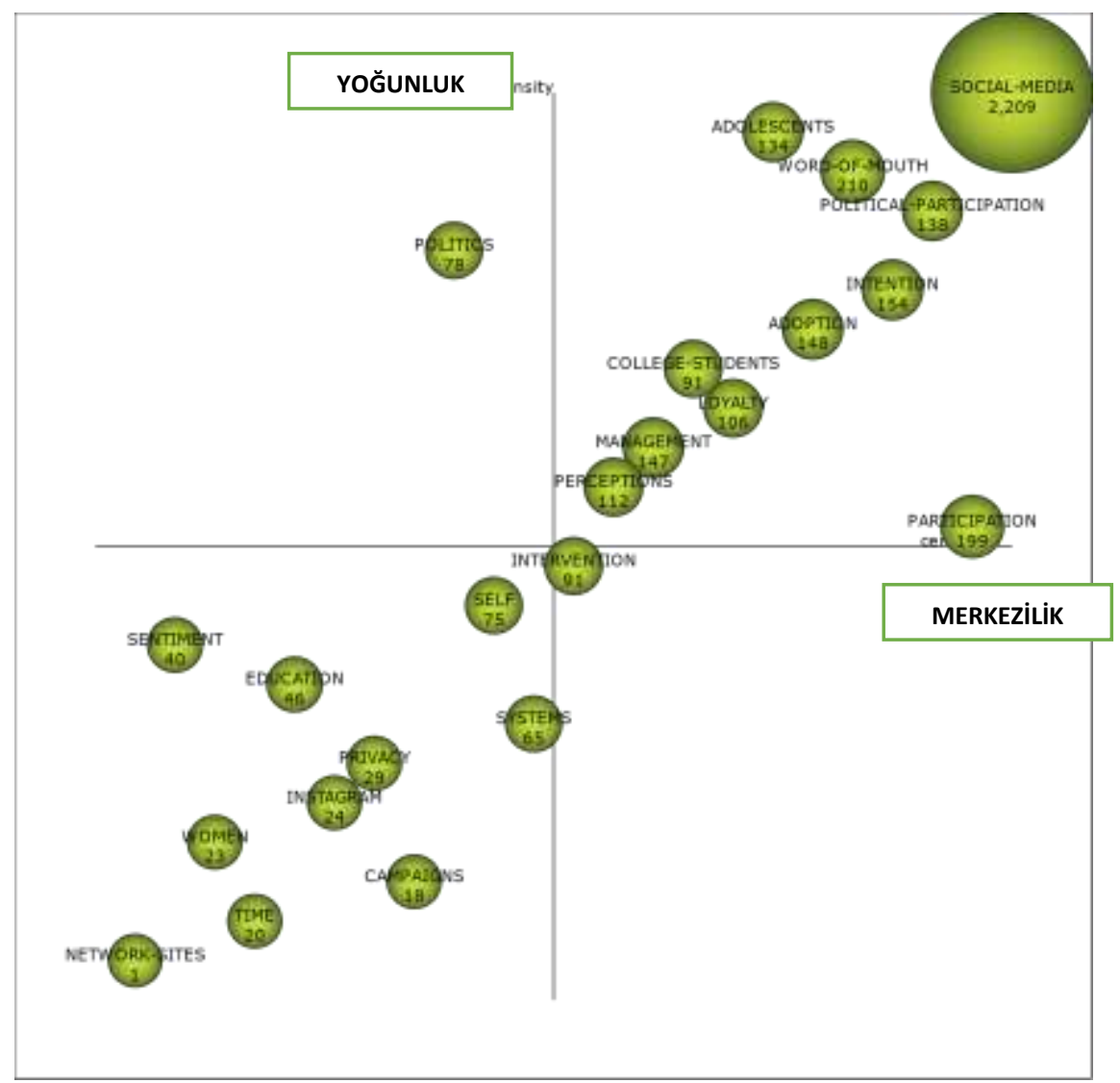

Diyagram 7. 2015-2019 Dönemi Stratejik Diyagramı

Sosyal medya alanında yapılan çalışmalarda, "politics" ise kendi içinde güçlü ancak izole bir yapıdadır. "İntervention" ise sosyal medya alanının gelişimi için önemli olan ancak yeterince çalışılmamış temadır. Ortaya çıkan 
veya kaybolan temalar; "self", "systems", "education", "privacy", "sentiment", "instagram", "campaigns", "women", "time", "network sites" "friends", "youth", "risk", "engagement” hem az çalışılmış hem de diğer tematik alanlar ile ilişki kuvveti zayıf olan dönemsel olarak güçlü olan temalardır.

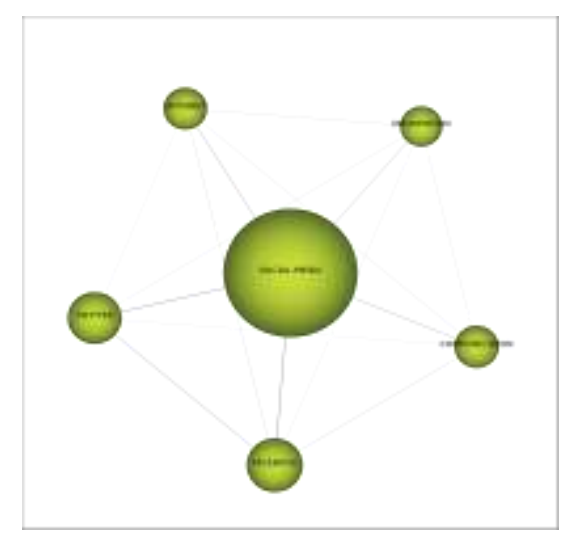

A: Social Media

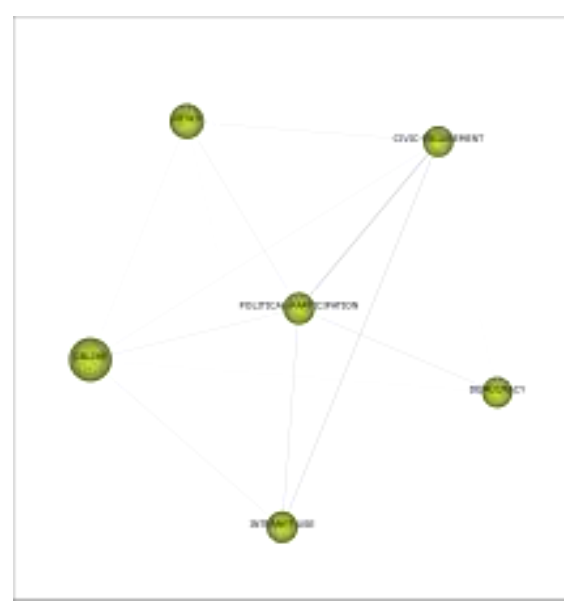

C: Political Participation

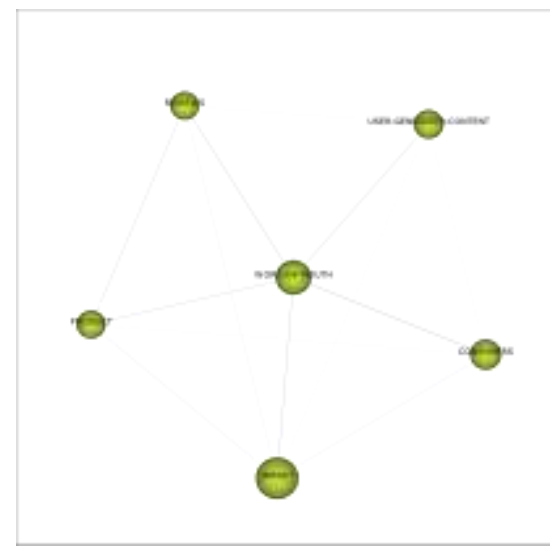

B: Word of mouth

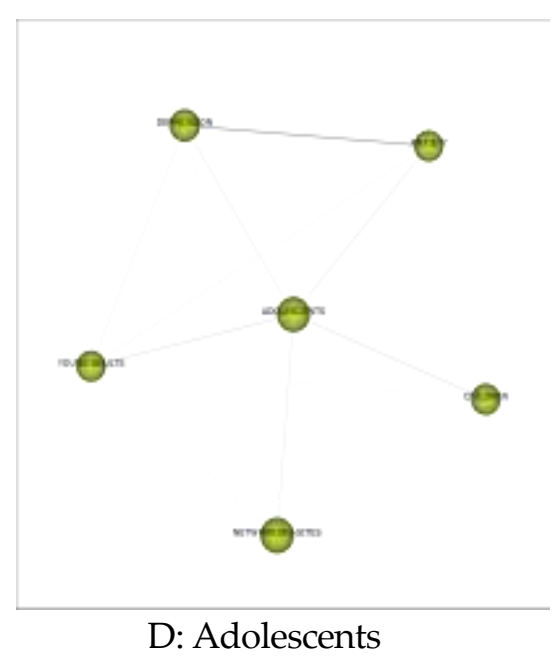




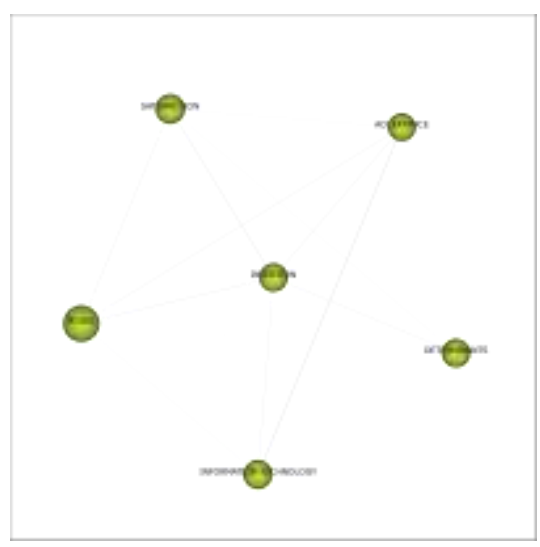

E: Intention

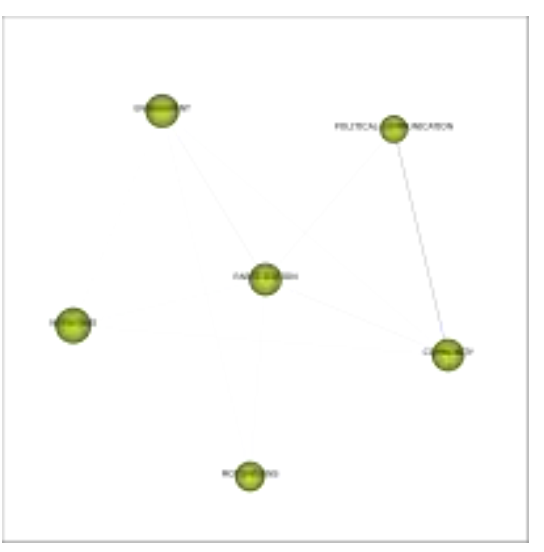

F: Participation

Diyagram 8. Tematik $A \breve{g}$

Tablo 2. 2015-2019 Dönemi Temalarna İlişkin Bulgular

\begin{tabular}{|c|c|c|c|}
\hline İsim & Doküman Sayısı & Atıf Sayısı & h-İndeksi \\
\hline Social media & 2,209 & 15,372 & 46 \\
\hline Word of mouth & 210 & 2,078 & 25 \\
\hline Participation & 199 & 1,484 & 20 \\
\hline Intention & 154 & 1,562 & 21 \\
\hline Adoption & 148 & 1,272 & 18 \\
\hline Management & 147 & 852 & 15 \\
\hline Political participation & 138 & 1,373 & 19 \\
\hline Adolescents & 134 & 1,046 & 15 \\
\hline Perceptions & 112 & 816 & 15 \\
\hline Loyalty & 106 & 1,168 & 18 \\
\hline College students & 91 & 1,085 & 17 \\
\hline Intervention & 91 & 608 & 12 \\
\hline Politics & 78 & 305 & 8 \\
\hline Self & 75 & 396 & 9 \\
\hline Systems & 65 & 704 & 15 \\
\hline Education & 46 & 350 & 10 \\
\hline Sentiment & 40 & 244 & 8 \\
\hline Privacy & 29 & 269 & 9 \\
\hline Instagram & 24 & 225 & 7 \\
\hline Women & 23 & 142 & 6 \\
\hline Time & 20 & 208 & 8 \\
\hline Campaigns & 18 & 122 & 6 \\
\hline Network sites & 1 & 0 & 0 \\
\hline
\end{tabular}

“Diyagram 8: Tematik Ağ" ve “Tablo 2: 2015-2019 Dönemi Temalarına İlişkin Bulgular"da, 2015-2019 döneminde motor tema sayısında belirgin bir 
artış olduğu için öne çıkan 6 motor temanın hangi konularla beraber çalışıldığı ve bu motor temaların bilimsel verileri aşağıda sunulmuş̧tur.

Diyagram $8 \mathrm{~A}^{\prime}$ da verilen tematik ağda görüldügü üzere "social media" temas1 "internet" $(w=0,07)$, "twitter" $(w=0,10)$, "facebook" $(w=0,12)$, "communication" $(w=0,07)$ ve "information" $(w=0,05)$ temaları ile ilişkilidir. Bu dönemin motor temalarından olan "social media" temasıyla ilişkili olarak 2.209 makale yayınlanmış ve bu temanın toplam atıf sayısının 15.372, h-indeksinin ise 46 olduğu belirlenmiştir. İnstagram'ın social media ile değerlendirmeye alınacak seviyede ilişkisinin çıkmamasında; Instagramın aynı zamanda diğer temalarlada yoğun ilişki göstermesi ve Instagram konusunda yapılan çalışmalarda sosyal medya anahtar kelimesinin yer almaması etkili olmuştur. Ayrıca, sosyal medya platformları arasında aktif sosyal medya kullanıcı sayısı oranı en çok artan Instagram olduğundan ve özellikle $Y$ ve $Z$ kuşaklarında popülerliğini artırmasından dolayı, Instagram başlı̆̆ında farklı konularda yapılan akademik çalışmaların sayısında artış olduğu Diyagram 7'den anlaşılmaktadır. Bu sebeplerden dolayı, Instagram ile social media özelinde bağımsız bir ilişki oluşmadığı değerlendirilmektedir.

Diyagram $8 \mathrm{~B}^{\prime}$ de verilen tematik ağda görüldügü üzere "word of mouth" temas1 "reviews" $(\mathrm{w}=0,04)$, "product" $(\mathrm{w}=0,03)$, "impact" $(\mathrm{w}=0,04)$, "consumers" $(w=0,05)$ ve "user generated content" $(w=0,03)$ temaları ile ilişkilidir. Motor temalardan "word of mouth" temasiyla ilişkili olarak 210 makale yayınlanmış ve bu temanın toplam atıf sayısının 2.078, h-indeksinin ise 25 olduğu belirlenmiştir.

Diyagram $8 C^{\prime}$ de verilen tematik ağda görüldüğü üzere "political perticipation" temas1 "news" $(w=0,02)$, "online" $(w=0,02)$, "internet use" $(w=0,03)$, "democracy" $(w=0,03)$ ve "civic engagement" $(w=0,08)$ temaları ile ilişkilidir. Motor temalardan "political participation" temasıyla ilişkili olarak 138 makale yayınlanmış ve bu temanın toplam atıf sayısının 1.373, h-indeksinin ise 19 olduğu belirlenmiştir.

Diyagram $8 \mathrm{D}^{\prime}$ de verilen tematik ağda görüldüğü üzere "adolescents" temas1 "depression" $(w=0,02)$, "young adults" $(w=0,04)$, "networking sites" $(\mathrm{w}=0,02)$, "children" $(\mathrm{w}=0,03)$ ve "anxiety" $(\mathrm{w}=0,03)$ temaları ile ilişkilidir. Motor temalardan "adolescents" temasıyla ilişkili olarak 134 makale yayınlanmış ve bu temanın toplam atıf sayısının 1.046, h-indeksinin ise 15 olduğu belirlenmiştir. 
Diyagram $8 \mathrm{E}^{\prime}$ de verilen tematik ağda görüldüğü üzere "intention" teması "satisfaction" $(\mathrm{w}=0,02)$, "model" $(\mathrm{w}=0,02)$, "information technology" $(\mathrm{w}=0,02)$, "determinants" $(\mathrm{w}=0,01)$ ve "acceptance" $(\mathrm{w}=0,02)$ temaları ile ilişkilidir. Motor temalardan "intention" temasıyla ilişkili olarak 154 makale yayınlanmış ve bu temanın toplam atıf sayısının 1.562, h-indeksinin ise 21 olduğu belirlenmiştir.

Diyagram $8 \mathrm{~F}^{\prime}$ de verilen tematik ağda görüldüğü üzere "participation" temasi "engagement" $(w=0,02)$, "networks" $(w=0,01)$, "motivations" $(w=0,01)$, "community" ( $\mathrm{w}=0,01)$ ve "political communication" $(\mathrm{w}=0,01)$ temaları ile ilişkilidir. Motor temalardan "participation" temasıyla ilişkili olarak 199 makale yayınlanmış ve bu temanın toplam atıf sayısının 1.484, h-indeksinin ise 20 olduğu belirlenmiştir.

Araştırmada ele alınan dönemler bazında ortaya çıkan Anahtar Kelimeler Örtüşüm Haritası Diyagram 9'da verilmiştir.

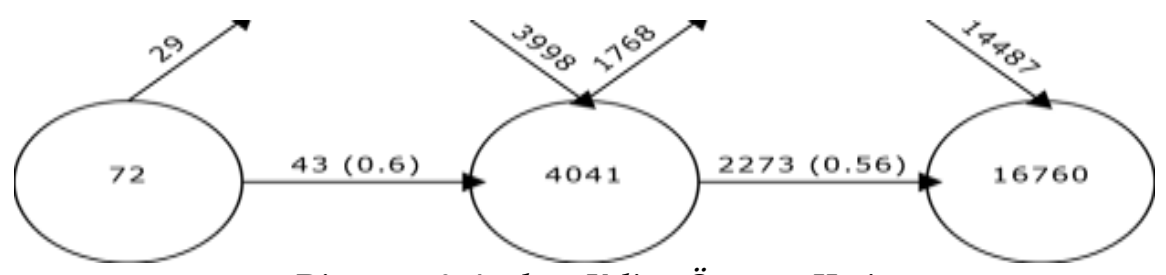

Diyagram 9. Anahtar Kelime Örtüşüm Haritası

Örtüşüm haritasında görüldüğü üzere ilk dönemde yer alan 72 anahtar kelimeden 43 adedi ikinci dönemde de kullanılmaya devam etmekte, 3998 yeni anahtar kelime bu dönemde kullanılmaya başlanmakta ve ikinci dönemde toplam 4041 anahtar kelime yer almaktadır. İkinci dönemde yer alan 4041 anahtar kelimeden 2273 adedi üçüncü dönemde de kullanılmaya devam etmekte, 14487 yeni anahtar kelime de bu dönemde kullanılmaya başlanmakta ve üçüncü dönemde toplam 16760 anahtar kelime yer almaktadır. Sosyal medya alanı ile ilişkili konu çeşitliliği ve bilimsel çalışma sayılarının her dönemde artış gösterdiği anlaşılmıştır.

\section{Sosyal Medya Konusunun Stratejik Gelişim Haritası}

Stratejik Gelişim Haritası aşağıda Diyagram 10'da sunulmuştur. 


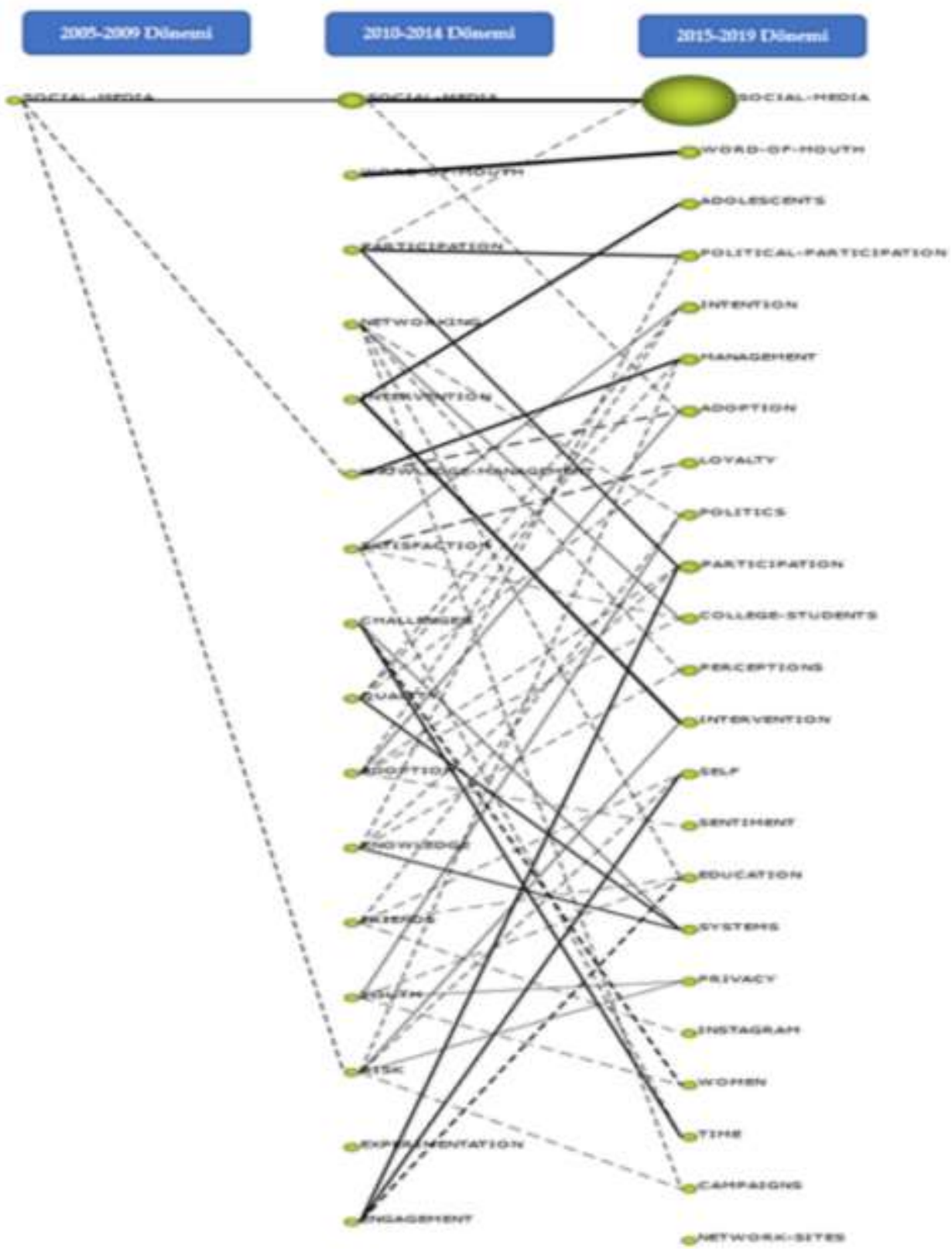

Diyagram 10. Stratejik Gelişim Haritası 
2005-2019 yılları arasında 15 yıllık dönemde oluşan tema sayılarına bakıldığında, 2005-2009 döneminde 1 adet, 2010-2014 döneminde 16 adet ve 20152019" döneminde ise 23 adet temanın oluştuğu görülmektedir. Bu durum, sosyal medya alanına olan ilginin sürekli olarak arttığın ifade etmektedir.

Stratejik gelişim haritasında "social media" temasının tüm dönemlerde yer aldığı, son iki dönem arasında ilişkinin daha da güçlendiği görülmektedir. "Word of mouth" teması son iki dönemde birbirleri ile güçlü bir ilişki gösterermektedir. "Participation" teması son iki dönemde yer alırken, son dönemden "political participation" ve "social media" temaları ile ilişki göstermektedir. "Intervention" teması son dönemlerde yar almakta ve son dönemden "adolescents" teması ile ilgili çalışmalarla bağ kurmaktadır. İkinci dönemde yer alan "knowledge management" teması ile ilgili çalışmaların son dönemde "management" ve "adoption" temalarına ilişkin çalışmalar ile ilişkili olduğu görülmektedir. "Challenges" temasının "systems", "women" ve "time" temaları ile birliktelik gösterdiği görülmektedir. "Quality" teması "systems" teması başta olmak üzere "intention", "management" ve "loyalty" temaları ile ilgili çalışmalarla ilişki içerisindedir. "Knowledge" teması başta "systems" teması olmak üzere "perceptions", "participation" ve "political participation" temaları ile ilişki göstermektedir. "Youth" teması "politics" ve "privacy" temalarının yanı sıra "education" ve "women" temaları ile bağ kurmaktadır. "Risk" teması "privacy", "intervention", "self" ve "management" temalarına ilişkin çalışmalarla ilişki çerisindedir. "Engagemant" teması "participation", "self" ve "education" temaları ile güçlü bir ilişki göstermektedir.

\section{Sonuç ve Öneriler}

Bibliyometrik analiz bilimsel yayın performansını inceleyen önemli yöntemlerden biridir. Bibliyometrik analiz ile araştırılan alana özgü bilgiler detaylı olarak ilişkiler ve örüntüler halinde elde edilebilir. Buradan elde edilecek sonuçlar, araştırılan konunun ülkeler nezdinde ne derece itibar gördüğü ve bu itibara göre bahse konu ülkelerin yayın politikasına yön vermesinde ve uluslararası yayın trendinin hangi konular/temalar ile ilgili olduğunun belirlenmesi açısından önemlidir. Bir diğer anlatımla, ülkenin ilgilenilen alan ile ilgili 
yayın politikasının geliştirilmesinde, uluslararası yayın trendinin bilim haritasını belirlemek oldukça önem arz etmektedir (Demir ve Erigüç, 2018).

Bu araştırmada, bilimsel haritalama yöntemi kullanılarak, WoS'ta dizinlenen yayınlar ile sosyal medya alanına ilişkin bilim haritası oluşturulmuştur. Oluşturulan stratejik gelişim haritası ve diyagramlar ile "2005-2009”, "20102014" ve "2015-2019" şeklinde beşer yıllık üç dönem halinde en çok çalışllan temaların hangileri olduğu belirlenerek karşılaştırmalı olarak analiz edilmiştir. Her üç döneminde en güçlü teması olan sosyal medyayı, kitlelerin bir ürün ya da olayı birbirlerine aktararak yayması durumunu ifade eden "word of mouth" (ağızdan ağıza) teması takip etmektedir. Bu temayı ise sirasıyla katılımcllık, niyet, benimseme, yönetim, politik katılım, ergenler, algı ve bağlılık kelimeleri gibi işletme, yönetim, pazarlama gibi bilim dallarında sıklıkla konu edilen temalar takip etmektedir.

Mangold ve Faulds (2009), müşterilerin doğrudan birbirleriyle konuşmalarının en iyi reklam araçlarından biri olduğunu ifade etmektedir ki "ağızdan ağıza iletişim" bu araştırmada motor temalardan biri olmuştur. Sosyal medya ile bir kişi yüzlerce, binlerce hatta milyonlarca kişiyle aynı anda etkileşim sağlayabildiği gibi, işletmeler ile de huzlı bir şekilde iletişim kurabilmektedir. $\mathrm{Bu}$ nedenle, ağızdan ağıza iletişim hem bireyler hem de işletmeler açısından önem kazanmıştır.

Sosyal medya etkileşimi kişilerin davranışlarına etki edebilmektedir (Nusair, Butt ve Nikhashemi, 2019). Etkileşimli web uygulamaları olarak da tanımlanabilen sosyal medyanın, küresel çapta, özellikle de ergenler ve genç yetişkinler arasında, artan ilgiyle birçok kullanım alanına sahip olduğunu belirten Zyoud, Sweileh, Awang ve Samah (2018), 2004-2015 yıllarına ait 959 yayını incelediklerinde, sosyal medyanın özellikle psikoloji alanında büyük bir ivme kazanarak yükselen bir trende sahip olduğunu belirtmişlerdir. $\mathrm{Bu}$ araştırma bulgularında ise aynı ivmenin devam ettiği görülmektedir. Nitekim 2015-2019 dönemine ait en önemli motor temalardan ikisinin "ergenler" ve "genç yetişkinler" teması olması ve bu temaların "depresyon", ve "anksiyete" temaları ile ilişkili olması sonucu bahse konu araştırma sonuçları ile uyumludur. Bu bağlamda sosyal medya teması ile birlikte özellikle son beş yılda yoğunluk ve merkezilik açısından motor temalar olarak değerlendirilen, ağızdan ağıza pazarlama, ergenler ve politik katılımcllık gibi alt temaları kapsayan konularda detaylı araştırmalar yapılarak önemli bulgulara ulaşılabilir. 
Chen, Wang, Tang ve Hao (2019) ise, 2009-2016 yıllarını kapsayan 565 yayın üzerinden yaptıkları bibliyometrik çalışmada, sosyal medyanın artan bir trend olduğu ve bu konuda Amerika Birleşik Devletleri ve Çin'in öncülük ettiğini tespit etmişlerdir. Bu sonuç araştırma bulgularını desteklemektedir.

Teknolojinin hızla değişimi, dönüşümü ve dinamik yapısı insanı ve insana dair tüm kavram ve olguları etkilemiştir. Teknolojik gelişmelerle birlikte insan ve toplum değişimi hızlanmıştır. İnternetin toplumsal hayat açısından vazgeçilmez olması durumu artık yadsınamaz bir gerçektir. X, Y, Z ve Alfa kuşaklarının teknolojiyi, interneti ve sosyal medyayı içselleştirme düzeyleri farklı olmakla birlikte, artık sahiplendikleri ve hatta onsuz yapamadıkları aşikârdır. Kuşaklar değiştikçe bireyler eskiye kıyasla daha kültürlü, daha bilgili, daha eğitimli ve daha farkındalık düzeyi yüksek hale gelmişlerdir. Şüphesiz teknolojinin gelişmesiyle bilginin artık daha ucuz hatta ücretsiz ve kolay erişilebilir olması bu durumda ana etkendir. Daha önceki kuşaklar açısından bir anlam ifade etmeyen nomofobi (cep telefonsuz kalma korkusu), netless (internetsiz kalma), fomo (fear of missing out-gelişmeleri kaçırma korkusu) gibi kavramlar ortaya çımaya başlamıştır. Kuşakların değişimi ve dönüşümü perspektifi ile sosyal medya mecraları, sosyal medyanın ifade ettiğ $i$ anlamlar, sosyal medya kullanım şekilleri zamanla farklılaşmıştır. Bu farklılık, odak noktasına sosyal medya kavramını alan bilimsel yayınlarda da kendini göstermiştir. Çalışma kapsamında, zaman içerisinde sosyal medya ile ilgili yayınlardaki kavram zenginliği ortaya konulmuştur.

Araştırmada veri kaynağı olarak sadece WoS, yazılım programı olarak da SciMAT programı kullanılmıştır. Araştırmacılar yapılacak benzer araştırmalarda Scopus gibi benzer veri tabanların kullanabilecekleri gibi Citespace, Vosviewer gibi başka programlar ve yazılımlar kullanarak farklı açılardan da konuyu derinlemesine analiz edebilir. WoS veri tabanında sosyal medya konusu ile ilgili bibliyometrik araştırmalara rastlanılmış olsa da SciMAT yazılımı ile yapılan bir araştırmaya rastlanılmamıştır. Bu araştırmanın sosyal medya alanına ilgi duyan tüm araştırmacılar ve paydaşlar açısından farkındalık oluşturabileceği ve önemli bir veri kaynağı olarak kullanılabileceği değerlendirilmektedir. 


\title{
EXTENDED ABSTRACT
}

\section{Bibliometric Analysis of Research on Social Media With Science Mapping Technique}

\author{
Serdar Akyıldız - Kadri Gökhan Yılmaz \\ Gazi University, Hacı Bayram Veli University
}

Today, internet has become a very important position that can directly affect life. More than half of the world's population is internet user and the number of these users is increasing day by day as the geographies reach by the internet expand. According to the "We Are Social (2020) report", 82\% of internet users in the world and $88 \%$ in Turkey are also social media users. As the usage area of social media has expanded, it has become a medium that attracts attention by people. People need the use of social media to learn about anything, provide social interaction, position their personal identity and have fun (Pitta, Kilian, Hennigs and Langner 2012). Social media has become an indispensable element in people's lives with these needs and has brought a lot of innovations to their lives as well as changing their habits by reaching a different position from traditional media. With the advances in information and communication technology and especially with the internet, it has become faster and easier for people to access information. One of the most important tools that provide this convenience is social media. Social media can be defined as online communities through electronic communication tools to share the content created by users. The rapidly increasing usage rate of social media in recent years has made social media not only an interpersonal communication medium but also turned it into a social communication tool. Today, social media used effectively in education and training activities, political communication campaigns, businesses, corporate image studies, public diplomacy, international relations, many areas of life and scientific studies.

This research has the importance of being one of the first studies on "bibliometric analysis of research on social media with the science mapping technique" in the literature review. In various fields, there are studies measuring scientific publication performance with different methods. One of the most important methods is "bibliometric analysis". With bibliometric analysis, 
findings giving specific information about the area can be identified. The conclusions to be drawn from these findings are important in determining the broadcasting policy of the countries and determining which topics/themes the international broadcasting trend is related to. In other words, it is very important to determine the science map of the international broadcasting trend in the development of the broadcasting policy of the country in the area of interest (Demir and Erigüç, 2018).

With the ever-increasing use of social media, the change in the number of studies conducted on social media in the literature has also been a subject of curiosity. Also, along with social media, which topics have been researched have also gained importance. In this context, revealing the thematic development map of the researches in the field of social media is important in terms of following new trends. With this research prepared for this purpose, the developments in the field of social media in the last fifteen years were analyzed periodically and systematically. Firstly, the article data to be used in the research were obtained from the Web of Science (WoS) Core Collection database. On 04.12.2019, the term "Social Media" was searched in the "title" section of the WoS database and 17.406 publications were reached. By using the SciMAT program, the bibliometric analysis was performed for 9,516 article data only through publications of the "article" type using the science mapping method. In this framework, using the scientific mapping method, a science map related to the social media field was created with the publications indexed in WoS. The most studied themes were determined by the strategic development map and diagrams created. As a result of the analysis, it has been observed that the number of articles published in the field of social media has increased significantly and the USA is the country with the highest number of publications. In terms of publications originating from Turkey, as Turkey has approximately $2 \%$ articles in citation index journals indexed within the scope of WoS in the field of social media and $0.4 \%$ articles in Turkish, it can be stated that publications in the field of social media in Turkey contribute to international literature with a small number of publications. In order to evaluate the development of social media on the basis of periods, the article data was analyzed comparatively in three periods of five years as "2005-2009", "2010-2014" and "2015-2019". As a result of the analysis, the motor theme of the period of "2005-2009" was "social media", the main motor themes of the period of "2010-2014" were "social media", "participation", 
"word-of-mouth marketing", "networking", and the main motor themes of the period of "2015-2019" were "social media", "word-of-mouth marketing", "political participation" and "adolescents". Social media, the strongest theme in all three periods, was followed by the theme "word of mouth," which refers to the situation where the masses spread a product or event by passing it on to each other. This theme was followed by themes that are frequently discussed in disciplines such as business, management and marketing, such as participation, intention, adoption, management, political participation, adolescents, perception and commitment. In this context, important findings can be reached by conducting detailed research on social media themes, including sub-themes such as word-of-mouth marketing, adolescents and political participation, which have been evaluated as motor themes in terms of intensity and centrality, especially in the last five years.

In this research, only WoS was used as data source and SciMAT was used as software program. Researchers can use similar databases such as Scopus in similar researches, as well as analyze the subject from different perspectives using other programs and software such as Citespace, VOSviewer. Although bibliometric research on social media has been found in the WOS database, no research has been found with SciMAT software. It is evaluated that this research can create awareness and be used as an important data source for all researchers and stakeholders who are interested in social media.

\section{Kaynakça / References}

Acet, O. (2013). Alternative media and democracy: Political participation and expresssion through social media in Turkey. Yayımlanmamış Yüksek Lisans Tezi, Bilkent Üniversitesi Ekonomi ve Sosyal Bilimler Enstitüsü, Ankara.

Aghaei, S. Nematbakhsh, M.A, Farsani, H.K. (2012).Evolution of the World Wide Web: From Web 1.0 to Web 4.0, International Journal of Web \& Semantic Technology (IJWesT) 3(1), 1-10. doi : 10.5121/ijwest.2012.3101

Alotaibi, N.M., Guha, D., Fallah, A., Aldakkan, A. Nassiri, F., Badhiwala, J.H., ...., Lozano, A.M. (2016) Social media metrics and bibliometric profiles of neurosurgical departments and journals: Is there a relationship? World Neurosurg. 90, 574-579. doi: 10.1016/j.wneu.2016.01.087

Bellis, N.D. (2009). Bibliometrics and citation analysis. From the science citation index to cybermetrics. The Scarecrow Press. Toronto, UK.

Bostanc, M. (2015). Sosyal medya ve siyaset. Konya: Palet Yayınları. 
Broadus, R.N. (1987). Toward a definition of “bibliometrics". Scientometrics, 12 (5-6), 373-379. doi: 10.1007/BF02016680

Budak, S. (2015). Halkla ilişkiler ve medya ilişkisi çerçevesinde basm bültenlerinin gazetelerde haber olarak değerlendirilmesi: Zaman ve hürriyet örneği. T.C. Selçuk Üniversitesi Sosyal Bilimler Enstitüsü Halkla Illişkiler ve Tanıtım Anabilim Dalı Doktora Tezi, Konya.

Cancino, C., Merigó, J.M., Coronado, F. Dessouky, Y. ve Dessouky M. (2017). Forty years of computers \& industrial engineering: A bibliometric analysis. Computers and Industrial Engineering, 113, 614-629, doi: 10.1016/j.cie.2017.08.033.

Castillo, C., Mendoza, M., ve Poblete, B. (2011). Information credibility on Twitter. WWW'11: Proceedings on the 20th International Conference on World Web. 675684. doi: 10.1145/1963405.1963500

CBSNEWS (2020). Then and now: a history of social networking sites, 02.01.2020 tarihinde https://www.cbsnews.com/pictures/then-and-now-a-history-ofsocial-networking-sites/2/ adresinden erişilmiştir.

Chen, C., (2017). Science mapping: a systematic review of the literature. Journal of Data and Information Science, 2(2), 1-40.

Chen, X., Wang, S., Tang, Y., ve Hao, T. (2019). A bibliometric ananlysis of event detection in social media. Online Information Review. 43(1), 29-52. doi: 10.1108/OIR-03-2018-0068.

Churchill D. (2009). Educational applications of Web 2.0: Using blogs to support teaching and learning. British Journal of Educational Technology 40(1), 179-83. doi: 10.1111/j.1467-8535.2008.00865.x

Cobo, M. J., López-Herrera, A. G., Herrera-Viedma, E., ve Herrera, F. (2012). SciMAT: A new science mapping analysis software tool. Journal of the American Society for Information Science and Technology, 63(8), 1609-1630. Doi: 10.1002/asi.22688

Cobo, M. J., Martínez, M.Á., Gutiérrez-Salcedo, M., Fujita, H., ve Herrera-Viedma, E. (2015). 25 years at knowledge-based systems: A bibliometric analysis. Knowledge-based systems, 80, 3-13. doi: 10.1016/j.knosys.2014.12.035

Çakmak, V.(2014). İletisim kaygısının sosyal medya kullanımı üzerine olan etkisi: Üniversite ögrrencileri ̈̈zerine örnek olay incelemesi. Yayımlanmamış Doktora Tezi, Selçuk Üniversitesi Sosyal Bilimler Enstitüsü Müdürlüğü, Konya.

Demir, H., ve Erigüç G. (2018). Bibliyometrik bir analiz ile yönetim düşünce sisteminin incelenmesi, İş ve İnsan Dergisi 5(2), 91-114. 25.01.2020 tarihinde https://dergipark.org.tr/tr/download/article-file/557505 adresinden erişildi. 
DergiPark, (2019). "Sosyal medya" anahtar kelimesi arama sonuçları. 10.01.2020 tarihinde, https://dergipark.org.tr/tr/search?q=\%22sosyal+medya\%22\&section=articles\&searchFields=rawTranslations.keywords adresinden erişilmiştir.

Eren Çetin, Ş. (2019). Katılımo kültür olgusu bağlamında sosyal medya ve çeorimiçi topluluklar: Netnografik bir analiz. Yayımlanmamış Doktora Tezi, Akdeniz Üniversitesi Sosyal Bilimler Enstitüsü. Antalya.

Jacso, P. (2005). As we may search--comparison of major features of the Web of Science, Scopus, and Google Scholar citation-based and citation-enhanced databases. Current Science, 89(9), 1537-1547.

Kaplan A.M., ve Haenlein M. (2010). Users of the world, unite! The challenges and opportunities of Social Media. Business Horizons, 53(1), 59-68. doi: 10.1016/j.bushor.2009.09.003

Karaca, P. (2019). Sosyal medya ve demokratik katılım ilişkisi: 24 Haziran 2018 Cumhurbaşkanlı̆̆ı seçim kampanyası'nda sosyal medya kullanımı. Yayımlanmamış Yüksek Lisans Tezi, İstanbul Yeni Yüzyıl Üniversitesi Sosyal Bilimler Üniversitesi, İstanbul.

Kurutkan, N., Orhan F. (2018b). Kalite prensiplerinin görsel haritalama tekniğine göre bibliyometrik analizi, Ankara:SAGE Yayınevi,

Kurutkan, N., ve Orhan F. (2018a). Sağhlk politikası konusunun bilim haritalama teknikleri ile analizi, IKSAD Yayınları.

Mangold, W.G., Faulds, D.J. (2009). Social media: The new hybrid element of the promotion mix. Business Horizons, 52, 357-365. doi: 10.1016/j.bushor.2009.03.002

Martínez, M. A., Cobo, M. J., Herrera, M., ve Herrera-Viedma, E. (2015). Analyzing the scientific evolution of social work using science mapping. Research on Social Work Practice, 25(2), 257-277. doi: 10.1177/1049731514522101

Mayfield, A. (2008). What is social media? iCrossing. 17.12.2019 tarihinde https://www.icrossing.com/uk/sites/default/files uk/insight pdf files/What $\% 20$ is \%20Social\%20Media iCrossing ebook.pdf adresinden erişilmiştir.

Merriam-webster, (2019). Social media, 26.12.2019 tarihinde https://www.merriam-webster.com/dictionary/social\%20media adresinden erişilmiştir.

Murgado-Armenteros, E. M., Gutiérrez-Salcedo, M., Torres-Ruiz, F. J. ve Cobo, M. J. (2015). Analysing the conceptual evolution of qualitative marketing research through science mapping analysis. Scientometrics, 102(1), 519-557. doi: 10.1007/s11192-014-1443-z 
Nusair, K., Butt, I., ve Nikhashemi, S.R. (2019). A bibliometric analysis of social media in hospitality and tourism research. International Journal of Contemporary Hospitality Management, 31(7), 2691-2719. doi: 10.1108/IJCHM-06-2018-0489

Parr, H. (2008). Mental health and social space: Towards Inclusionary Geographies? Wiley Online Library. doi:10.1002/9780470712924.

Petticrew, M., ve Roberts, H. (2008). Systematic reviews in the social sciences: A practical guide. Wiley Online Library. doi: $10.1002 / 9780470754887$.

Pritchard, A. (1969). Statistical bibliography or bibliometrics? Journal of Documentation 25(4), 348-349.

Sayımer, İ. (2008). Sanal ortamda halkla ilişkiler. İstanbul:Beta Yayınları.

SciMAT, (2019). Science Mapping Analysis Tool, 05.12.2019 tarihinde https://sci2s.ugr.es/scimat/ adresinden erişilmiştir.

Statista (2019a) Number of monthly active Instagram users from January 2013 to June 2018.

19.12.2019 tarihinde, https://www.statista.com/statistics/253577/number-ofmonthly-active-instagram-users/ adresinden erişilmiştir.

Statista (2019b) Percentage of U.S. adults who use Instagram as of January 2018, by age group. 19.12.2019 tarihinde, https://www.statista.com/statistics/246199/share-of-us-internet-users-who-use-instagram-by-age-group/ adresinden erişilmiştir.

Su F. ve Beaumont C. (2010). Evaluating the use of a wiki for collaborative learning. Innovations in Education and Teaching International 47(4), 417-431. doi: 10.1080/14703297.2010.518428

Tabak, A., Barbak A. ve Öztürk T., (2016). Kamu politikası disiplininin kavramsal gelişimini bibliyometri kullanarak anlamak mümkün mü?:1980-2014 döneminin bilimsel haritalama analizi. EUL Journal of Social Sciences, 7(2), 117-143

Tiggemann, M. ve Anderberg I. (2019). Social media is not real: The effect of 'Instagram vs reality' images on women's social comparison and body image. New Media E Society, 1-17. doi: 10.1177/1461444819888720

Vural, Z.B.A., ve Bat, M. (2010). Yeni bir yerleşim ortamı olarak sosyal medya: Ege Üniversitesi İletişim Fakültesine Yönelik bir Araştırma. Journal of Yaşar University, 20(5), 3348-3382.

Wearesocial, (2019). The global state of digital in october 2019. 15.12.2019 tarihinde https://wearesocial.com/blog/2019/10/the-global-state-of-digital-in-october 2019 adresinden erişilmiştir.

Web of Science, (2019). The world's largest publisher-neutral citation index and research intelligence platform, 04.12.2019 tarihinde https://www.webofknowledge.com adresinden erişilmiştir. 
Wheeler S., Yeomans P. ve Wheeler D. (2008). The good, the bad and the wiki: Evaluating student-generated content for collaborative learning. British Journal of Educational Technology 39(6), 987-95. doi: 10.1111/j.1467-8535.2007.00799.x

Yükseköğretim Kurulu Başkanlığı [YÖK] (2019). Tez Merkezi , 15.12.2019 tarihinde https://tez.yok.gov.tr/UlusalTezMerkezi/tezSorguSonucYeni.jsp adresinden erişilmiştir.

Zyoud, S.H., Sweileh, W.M., Awang, R. ve Samah, W.A. (2018). Global trends in research related to social media in psychology: mapping and bibliometric analysis. Int J.Ment Health Syst, 12(4), doi: 10.1186/s13033-018-0182-6.

\section{Ekler}

Ek 1. 2005-2009 Dönemi Temalarına İlişkin Bulgular

\begin{tabular}{|l|l|}
\hline Social Media & Sosyal medya \\
\hline Management & Yönetim \\
\hline Internet & Internet \\
\hline Public Relations & Halkla ilişkiler \\
\hline World Wide Web & Dünya Çapında A $\breve{g}$ \\
\hline
\end{tabular}

Ek 2. 2010-2014 Dönemi Temalarına İlişkin Bulgular

\begin{tabular}{|l|l|}
\hline Social media & Sosyal Medya \\
\hline Participation & Katılım \\
\hline Word of mouth & Ağızdan ağıza \\
\hline Networking & Ă̆ \\
\hline Knowledge management & Bilgi Yönetimi \\
\hline Intervention & Müdahale \\
\hline Quality & Kalite \\
\hline Satisfaction & Memnuniyet \\
\hline Adoption & Benimseme \\
\hline Knowledge & Bilgi \\
\hline Challenges & Zorluklar, Mücadeleler \\
\hline Experimentation & Deneme \\
\hline Friends & Arkadaşlar \\
\hline Risk & Risk \\
\hline Youth & Gençlik \\
\hline Engagement & Bağlantı, Katılım \\
\hline 6A "Social Media" ilişik olduğu temalar & \\
\hline Twitter & Twitter \\
\hline Facebook & Facebook \\
\hline Communication & İletişim, Haberleşme \\
\hline Web 2.0 & Web 2.0 \\
\hline & \\
\hline
\end{tabular}




\begin{tabular}{|l|l|}
\hline 6B "Participation" ilişik olduğu temalar & \multicolumn{2}{|l|}{ Bilgi } \\
\hline Information & İnternet üzerinden \\
\hline Online & Ağlar \\
\hline Networks & İnternet kullanımı \\
\hline Internet Use & Siyasi Katılım \\
\hline Political Participation & \multicolumn{2}{|l|}{} \\
\hline 6C "Word of Mouth" ilişik olduğu temalar & Satışlar \\
\hline Sales & Gözden geçirmeler \\
\hline Reviews & Etki \\
\hline Impact & Tüketiciler \\
\hline Consumers & Kullanıcı Tarafından Oluşturulan İçerik \\
\hline User Generated Content & \\
\hline 6D "Networking" ilişik olduğu temalar & Profesyonellik \\
\hline Professionalizm & Sosyal ağ \\
\hline Social networking & Ahlâk \\
\hline Ethics & Öğrenciler \\
\hline Students & Yaş \\
\hline Age &
\end{tabular}

\section{5-2019 Dönemi Temalarına İlişkin Bulgular}

\begin{tabular}{|l|l|}
\hline Social media & Sosyal medya \\
\hline Word of mouth & Ağıdan ağıza \\
\hline Participation & Katılım \\
\hline Intention & Niyet \\
\hline Adoption & Benimseme \\
\hline Management & Yönetim \\
\hline Political participation & Siyasi katılım \\
\hline Adolescents & Ergenler \\
\hline Perceptions & Algılar \\
\hline Loyalty & Sadakat \\
\hline College students & Üniversite öğrencileri \\
\hline Intervention & Müdahale \\
\hline Politics & Siyaset \\
\hline Self & Öz \\
\hline Systems & Sistemler \\
\hline Education & Ĕgitim \\
\hline Sentiment & Duygusallık \\
\hline Privacy & Gizlilik \\
\hline Instagram & Instagram \\
\hline Women & Kadınlar \\
\hline Time & Zaman \\
\hline Campaigns & Kampanyalar \\
\hline Network sites & A ̆̆ siteleri \\
\hline 8A "Social Media" ilişik olduğu temalar & \\
\hline Twitter & Twitter \\
\hline
\end{tabular}




\begin{tabular}{|l|l|}
\hline Facebook & Facebook \\
\hline Communication & İletişim, Haberleşme \\
\hline İnformation & Bilgi \\
\hline 8B " Word of mouth " ilişik olduğu temalar & Gözden geçirmeler \\
\hline Reviews & Ürün \\
\hline Product & Etki \\
\hline İmpact & Tüketiciler \\
\hline Consumers & Kullanıc Tarafından Oluşturulan İçerik \\
\hline User generated content & \multicolumn{2}{|l|}{} \\
\hline 8C " Political Participation" ilişik olduğu temalar & Haberler \\
\hline News & İnternet üzerinden \\
\hline Online & İnternet kullanımı \\
\hline İnternet use & Demokrasi \\
\hline Democracy & Sivil katıllım \\
\hline Civic engagement & \multicolumn{2}{|l|}{} \\
\hline 8D "Adolescents" ilişik olduğu temalar & Depresyon \\
\hline Depression & Genç yetişkinler \\
\hline Young adults & Ağ siteleri \\
\hline Networking sites & Çocuklar \\
\hline Children & Anksiyete \\
\hline Anxiety & \\
\hline 8E "İntention" ilişik olduğu temalar & Memnuniyet \\
\hline Satisfaction & Model \\
\hline Model & Bilgi teknolojisi \\
\hline İnformation technology & Belirleyici faktörler \\
\hline Determinants & Kabul \\
\hline Acceptance & \multicolumn{2}{|l|}{} \\
\hline 8F "Participation" ilişik olduğu temalar & Bağlantı, Katılım \\
\hline Engagement & Ağlar \\
\hline Networks & Motivasyonlar \\
\hline Motivations & Topluluk \\
\hline Community & Siyasal iletişim \\
\hline Political communication & \\
\hline & \\
\hline
\end{tabular}

\section{Kaynakça Bilgisi / Citation Information}

Akyıldız, S. ve Yılmaz, K. G. (2020). Sosyal medya konulu araştırmaların bilim haritalama tekniği ile bibliyometrik analizi. OPUS-Uluslararası Toplum Araştırmaları Dergisi, 16(28), 1416-1451. DOI: 10.26466/opus.680835 